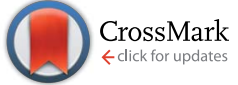

Cite this: RSC Adv., 2015, 5, 70689
Received 18th May 2015

Accepted 10th August 2015

DOI: $10.1039 / \mathrm{c} 5 \mathrm{ra09302c}$

www.rsc.org/advances

\section{Marine inspired antiplasmodial thiazinoquinones: synthesis, computational studies and electrochemical assays $\uparrow$}

\author{
C. Imperatore, $\star^{a}$ M. Persico, $\ddagger^{a}$ A. Aiello, ${ }^{a}$ P. Luciano, ${ }^{a}$ M. Guiso, ${ }^{b}$ M. F. Sanasi, ${ }^{b}$ \\ D. Taramelli, ${ }^{c}$ S. Parapini, ${ }^{c}$ G. Cebrián-Torrejón, ${ }^{d}$ A. Doménech-Carbó, ${ }^{\star d}$ \\ C. Fattorusso*a and M. Menna*a
}

In the search for new antimalarials, we used the quinone scaffold of marine secondary metabolites as a chemical starting point to synthesize new thiazinoquinone compounds. Most of synthetic derivatives have shown a significant pharmacological activity and some structural requirements, critical for both the antiplasmodial effect and cytotoxicity, have been evidenced. The redox properties of the prepared compounds have been investigated by computational studies and electrochemical assays, which indicated that a higher antiplasmodial activity of some thiazinoquinones is related to their greater ability to form the semiquinone species and strongly interact with free Fe(III)-protoporphyrin IX.

\section{Introduction}

The available chemical entities to treat malaria cases are still currently based on a few chemical scaffolds, some of them quite old, like the anti-folates or the 4-aminoquinoline derivatives. Although the combination of these molecules with artemisinins and other endoperoxide analogues is at present the recommended treatment for uncomplicated malaria with excellent results, the therapeutic choices are still too limited and the prospect of resistance is high. ${ }^{\mathbf{1 , 2}}$ However, a few new drug targets or classes of drugs have been recently clinically validated, and, therefore, a continuous search for effective and innovative drugs, with both unique structures and new mechanisms of action to treat sensitive and drug-resistant strains of parasites, stands to reason..$^{3-6}$

\footnotetext{
${ }^{a}$ The NeaNat Group, Dipartimento di Farmacia, Università degli Studi di Napoli Federico II, Via D. Montesano 49, 80131 Napoli, Italy. E-mail: mlmenna@unina.it; cfattoru@unina.it; Tel: +39-081 678518; +39-081678544

${ }^{b}$ Dipartimento di Chimica, Università di Roma La Sapienza, P. Aldo Moro 5, 00185 Roma, Italy

'Dipartimento di Scienze Biomediche, Chirurgiche e Odontoiatriche, Università di Milano, Via Pascal 36, I-20133 Milano, Italy

${ }^{d}$ Departament de Quimica Analítica, Facultat de Quimica, Universitat de València, Dr. Moliner 50, 46100 Burjassot, Valencia, Spain. E-mail: antonio.domenech@uv.es; Tel: $+34-9635-43157$

$\dagger$ Electronic supplementary information (ESI) available: Reagents and general experimental procedure, purity for tested compounds, MS and 1D- and 2D-NMR spectra of compounds $\mathbf{1 7}$ and 20, and MS and 1D-NMR spectra of compounds 18-19 and 21-22. Calculated prevalent ionic forms of thiazinoquinones, $\mathbf{Q H}_{\mathbf{i}}{ }_{\mathrm{i}}$ and $\mathrm{QH}{ }_{\mathrm{ii}}$ species of 12, 15, 19, and $22 \mathrm{GM}$ conformers. PM7 GM conformers of 12 and 15. \% Inhibition of BH formation by chloroquine and test compounds. See DOI: $10.1039 / \mathrm{c} 5 \mathrm{ra} 09302 \mathrm{c}$

\$ These authors contributed equally.
}

A drug directed against Plasmodium should be active orally for 1-3 days, should give a fast eradication of parasite and disappearance of symptoms, and should be safe for children and pregnant women. Furthermore, since malaria primarily affects the world's most disadvantaged populations, an antimalarial drug should be affordable. To reach these challenging aims, the identification and selection of new lead compounds constitutes a crucial point. In this regard, nature remains an ever evolving resource; bioactive natural compounds form a rich source of unique chemical scaffolds suited for optimization to obtain new improved therapeutics. The use of medicinal plants for the treatment of parasitic diseases is well known and documented since ancient times, ${ }^{7,8}$ but the screening of biologically active natural compounds with potential antimalarial activity, isolated from both terrestrial $^{\mathbf{8 , 9}}$ and marine ${ }^{\mathbf{1 0 , 1 1}}$ organisms, is still now of considerable interest. Recently, the antiplasmodial activity of marine secondary metabolites of quinone structures has been reported. They include the xestoquinone (1), its derivative orlaquinone (2), and ketoadociaquinones A and B (3 and 4) isolated from Xestospongia species, ${ }^{12,13}$ and thiaplakortones A-D (5-8) isolated from Plakortis lita. ${ }^{\mathbf{1 4}}$ (Fig. 1). It is worth to point out that a number of quinones have been shown to be effective antimalarials; the observed effects are most likely related to the most prominent chemical feature of these kind of molecules, that is their ability to undergo redox cycling. The most glaring example is atovaquone, a hydroxynapthoquinone currently used as a fixed-dose combination with proguanil (Malarone). This drug is the outcome of half century of research by many groups which explored the use of quinones against different parasitic diseases, including malaria and toxoplasmosis. ${ }^{15}$ 
<smiles>C[C@]12CCCc3coc(c31)C(=O)c1cc3c(cc12)C(=O)C=CC3=O</smiles>
1<smiles>[NH3+]CCc1c[nH]c2c1C(=O)C1=C(NC=CS1(=O)=O)C2=O</smiles>

5<smiles>CC1=CCCC2(C)C1=C(O)C(=O)c1cc3c(cc12)C(=O)C=CC3=O</smiles>

2

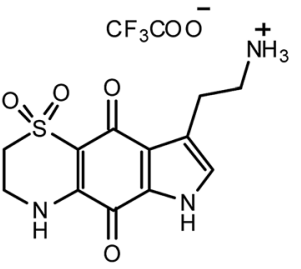

6<smiles>C[C@]12CCC(=O)c3coc(c31)C(=O)c1cc3c(cc12)C(=O)C1=C(NCCS1(=O)=O)C3=O</smiles>

3<smiles>C[NH2+][C@H](Cc1c[nH]c2c1C(=O)C1=C(NC=CS1(=O)=O)C2=O)C(=O)O</smiles>

7<smiles>C[C@]12CCC(=O)c3coc(c31)C(=O)c1cc3c(cc12)C(=O)C1=C(NCCS1(=O)=O)C3=O</smiles><smiles>C[NH2+][C@H](Cc1c[nH]c2c1C(=O)C1=C(C2=O)S(=O)(=O)C=CN1)C(=O)O</smiles>

8

Fig. 1 Structures of natural antimalarial quinones isolated from marine organisms.

Interestingly, pharmacological studies on compounds 1-8 evidenced that presence of a dioxothiazine moiety fused to the quinone moiety to give the thiazinoquinone scaffold enhances the antiplasmodial activity. ${ }^{14}$ Previously, we have recognized the condensation reaction of hypotaurine with quinones, using the known conjugate addition reaction of amines and sulfinic acids, as a simple and versatile way to synthesize a series of analogues of a marine natural thiazinoquinone, aplidinone A (9), isolated from the Mediterranean ascidian Aplidium conicum $^{16,17}$ (compounds 11-16, Fig. 2). Therefore, having identified the thiazinoquinone as a possible chemotype active against Plasmodium falciparum, we have adapted this synthetic approach to prepare additional analogues featuring this chemical scaffold with simplified side chains and different substituents. Compounds 17-22, related to aplidinone B (10), also found in A. conicum ${ }^{16}$ have been thus synthesized (Fig. 2).

Here we report the synthesis of compounds 17-22, the antiplasmodial effects in vitro of both methoxy- (11-16) and amidothiazinoquinones (17-22), as well as their toxicity against

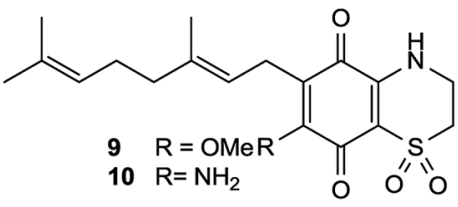<smiles>[R]C1C(=O)C2=C(C(CCC)C1=O)S(=O)(=O)CCN2</smiles>

$11 \mathrm{R}=-\mathrm{OMe} ; \mathrm{n}=1$

$12 \mathrm{R}=-\mathrm{OMe} ; \mathrm{n}=7$

$13 \mathrm{R}=-\mathrm{OMe} ; \mathrm{n}=13$

$16 \mathrm{R}=-\mathrm{OMe} ; \mathrm{n}=13$

$\mathrm{R}=-\mathrm{NHCOC}\left(\mathrm{CH}_{3}\right)_{3} ; \mathrm{n}=1 \quad 20 \mathrm{R}=-\mathrm{NHCOC}\left(\mathrm{CH}_{3}\right)_{3} ; \mathrm{n}=1$

$18 \mathrm{R}=-\mathrm{NHCOC}\left(\mathrm{CH}_{3}\right)_{3} ; \mathrm{n}=4 \quad 21 \mathrm{R}=-\mathrm{NHCOC}\left(\mathrm{CH}_{3}\right)_{3} ; \mathrm{n}=4$

$19 \mathrm{R}=-\mathrm{NHCOC}\left(\mathrm{CH}_{3}\right)_{3} ; \mathrm{n}=1022 \mathrm{R}=-\mathrm{NHCOC}\left(\mathrm{CH}_{3}\right)_{3} ; \mathrm{n}=10$

Fig. 2 Structures of aplidinones A and B and their synthetic analogues. human cells. Investigations into the putative antimalarial mechanism of action of the new thiazinoquinones 11-22 by computational studies and electrochemical assays are described here, too.

\section{Results and discussion}

\section{Chemistry}

The performed syntheses used inexpensive chemicals and required relatively few steps. As for compounds 11-16, the key step of the synthesis of compounds 17-22 has been the reaction between hypotaurine and a suitable benzoquinone to give the thiazinoquinone scaffold. ${ }^{17}$ The 2,5-dimethoxy-aniline (23) has been chosen as starting compound, because it already contains the amino group and it is a cheap product. The first performed synthetic step was the transformation of the amino group into an amide function by treating $\mathbf{2 3}$ with trimethylacetyl (pivaloyl, Piv) chloride; the lack of $\alpha$-hydrogens in this chloride ensured a better stability during the next reactions. The $N$-(2,5-dimethoxyphenyl) pivalamide 24 was obtained with a very good yield (95\%) (Scheme 1). Since direct alkylation by $n$-BuLi and alkyl bromides, as described for the synthesis of aplidinone A derivatives ${ }^{17}$ gave the alkylation products only in little quantity, $\mathbf{2 4}$ was treated with $n$-BuLi and DMF and afforded selectively the $N$-(2-formyl-3,6dimethoxyphenyl) pivalamide $(25,68.5 \%$ yield $)$. The subsequent Grignard reaction between the aldehyde $\mathbf{2 5}$ and three different alkyl magnesium iodides afforded the corresponding benzyl alcohols 26a-c with very good yields, especially for compounds 26a and 26b (99\%). Easy hydrogenolysis of benzyl alcohols 26a-c by using Pd/C (10\%) as catalyst gave compounds 27a-c in $92-97 \%$ yields. The quinones $28 \mathbf{a}-\mathbf{c}$ were obtained by oxidation of compounds $27 \mathbf{a}-\mathbf{c}$, respectively, with a large excess of cerium ammonium nitrate (CAN) in $99 \%$ yield. The steps from 26a-c to 28a-c do not require any intermediate purification, so simplifying the carrying out of the whole synthesis. Reaction of quinones 28a-c with hypotaurine, as reported in literature, ${ }^{18,19}$ gave the desired thiazinoquinones as mixtures of two regioisomers ( $\mathbf{1 7}$ and $\mathbf{2 0}$ from $\mathbf{2 8 a}, 18$ and $\mathbf{2 1}$ from $\mathbf{2 8 b}, 19$ and 22 from $28 c$, respectively). 


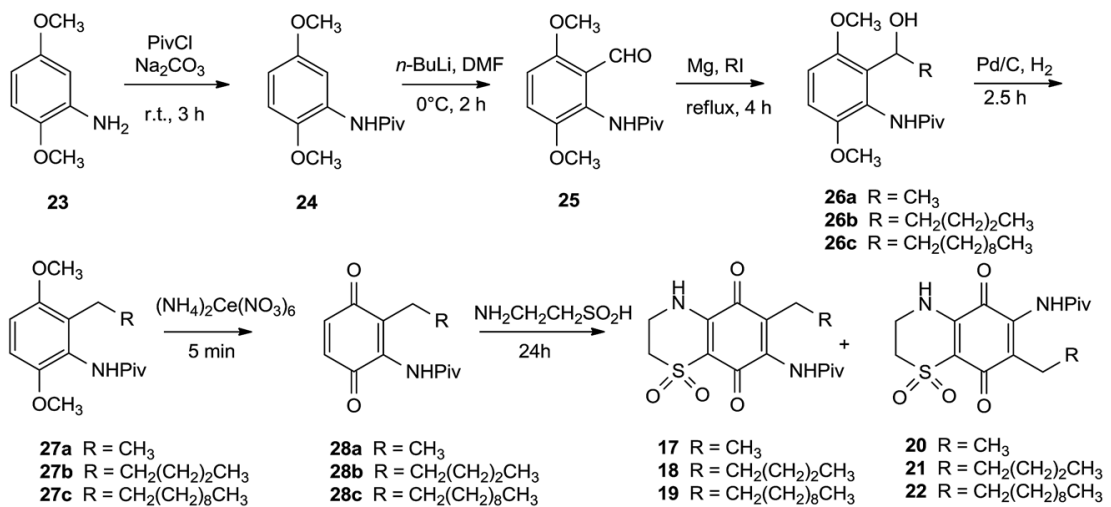

Scheme 1 Synthesis of thiazinoquinones 17-22.

HPLC separation of each regioisomers mixture on a silica gel column (see Experimental section) gave the pivaloyl-thiazinoquinones 17-22 as pure compounds.

The structures of the target alkyl thiazinoquinones as well as those of the intermediates $\mathbf{2 4}, \mathbf{2 5}, \mathbf{2 6 a}-\mathbf{c}, \mathbf{2 7 a - c}$, and 28a-c were established mainly using 1D and 2D NMR spectroscopy (see Experimental section). In particular, discrimination between the two isomeric structures for the compounds couples 17/20, 18/21, and 19/22 was achieved by interpretation of their HMBC spectra which allowed the position of the alkyl group with respect to nitrogen and sulfur atoms of the heterocyclic ring, to be assigned. As an instance, diagnostic cross peaks were present in the HMBC spectrum (DMSO) of compound 17 between the methylene protons at $\delta 2.28\left(2 \mathrm{H}-1^{\prime}\right)$ and the carbonyl resonance at $\delta 180.6$ (C-5), as well as between the sulfur-linked methylene protons at $\delta$ $3.35(2 \mathrm{H}-2)$ and the other carbonyl signal at $\delta 173.2(\mathrm{C}-8)$. This defined the structure of 17 as $N$-(6-ethyl-1,1,5,8-tetraoxo-3,4,5,8tetrahydro- $2 H$-benzo $[b][1,4]$ thiazin-7-yl)pivalamide, representative of the isomeric structure with the alkyl chain linked at C-6 named regioisomer A (RA). The alternative $N$-(7-ethyl-1,1,5,8-tetraoxo-3,4,5,8-tetrahydro- $2 H$-benzo $[b][1,4]$ thiazin-6-yl)pivalamide structure, named regioisomer B (RB), was assigned to 20 based on the correlation peaks present in its HMBC spectrum (DMSO) between both $1^{\prime}$ - and 2-methylene protons and the same carbonyl signal at $\delta 176.6$ (C-8). The whole series of HMBC correlations were consistent with the proposed assignment

Table 1 NMR (DMSO) data of compounds 17 and 20

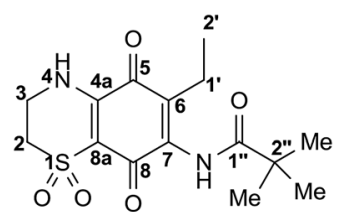

17

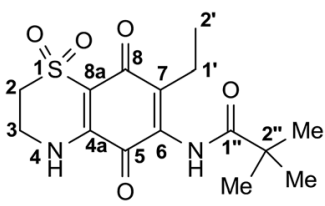

20

\begin{tabular}{|c|c|c|c|c|c|c|}
\hline & $\delta_{\mathrm{C}}$ & $\delta_{\mathrm{H}}$, mult. $(J$ in $\mathrm{Hz})$ & HМBC & $\delta_{\mathrm{C}}$ & $\delta_{\mathrm{H}}$, mult. $(J$ in $\mathrm{Hz})$ & HМBC \\
\hline 1 & - & - & - & - & - & - \\
\hline 2 & 48.5 & $3.35 \mathrm{~m}$ & $3,8 a, 8$ & 48.6 & $3.37 \mathrm{~m}$ & $3,8 \mathrm{a}, 8$ \\
\hline 3 & 40.0 & $3.81 \mathrm{~m}$ & $2,4 \mathrm{a}$ & 39.9 & $3.80 \mathrm{~m}$ & $2,4 \mathrm{a}$ \\
\hline 4 & - & - & - & - & - & - \\
\hline $4 a$ & 146.1 & - & - & 145.4 & - & - \\
\hline 5 & 180.6 & - & - & 176.7 & - & - \\
\hline 6 & 137.8 & - & - & 136.8 & - & - \\
\hline 7 & 140.2 & - & - & 147.6 & - & - \\
\hline 8 & 173.2 & - & - & 176.6 & - & - \\
\hline $8 \mathbf{a}$ & 108.1 & - & - & 109.6 & - & - \\
\hline $\mathbf{1}^{\prime}$ & 19.8 & $2.28, \mathrm{q}(7.5)$ & $5,6,7,2^{\prime}$ & 19.1 & $2.36, \mathrm{q}(7.5)$ & $6,7,8,2^{\prime}$ \\
\hline $2^{\prime}$ & 12.1 & $0.95, \mathrm{t}(7.5)$ & $6,1^{\prime}$ & 13.1 & $0.94, \mathrm{t}(7.5)$ & $7,1^{\prime}$ \\
\hline $1^{\prime \prime}$ & 177.2 & - & - & 178.0 & $3.91 \mathrm{~s}$ & - \\
\hline $2^{\prime \prime}$ & 38.8 & - & - & 39.1 & & - \\
\hline $\mathrm{Me}$ & 27.5 & 1.22 & $1^{\prime \prime}, 2^{\prime \prime}$ & 27.5 & & $1^{\prime \prime}, 2^{\prime \prime}$ \\
\hline $\mathrm{NH}$ & - & 9.11 , br s & $2,3,5$ & - & 9.10 , br s & $2,3,4 a, 5$ \\
\hline $\mathrm{NH}$ & - & $8.90 \mathrm{~s}$ & $7,8,1^{\prime \prime}$ & - & $9.03, \mathrm{~s}$ & $5,6,7,1^{\prime \prime}$ \\
\hline
\end{tabular}


(Table 1). Analogously, the position of the alkyl chain relative to the dioxothiazine ring in the remaining regioisomers couples was univocally assigned as depicted in Fig. 2 (Table 1SI†).

\section{Antiplasmodial activity and cytotoxicity}

Using the pLDH assay, compounds 11-22 have been tested for their in vitro antiplasmodial activity against both chloroquine (CQ)-sensitive (D10) and -resistant (W2) strains of P. falciparum; cytoxicity against human microvascular endothelial (HMEC-1) cells has been also evaluated. The $\mathrm{IC}_{50}$ values obtained, reported in Table 2, show that the most active compounds have antiplasmodial activity in the low micromolar/high nanomolar range with the regiochemistry of the dioxothiazine ring playing a role on the observed activity. In particular, when $\mathrm{R}_{1}$ is OMe group, only the regioisomer $\mathrm{B}(\mathrm{RB})$ resulted active (11-13 vs. 1416, Table 2), whereas, when $R_{1}$ is a PivNH substituent, the regioisomer $A(R A)$ resulted significantly more active than the RB (17-19 vs. 20-22, Table 2). The same regiochemistrydepending trend is observed for the cytotoxicity against human cells (HMEC-1), see Table 2. Nevertheless, the length of the alkyl side chain can distinguish the antiplasmodial from the cytotoxic activity. Indeed, in all active regioisomers, the toxicity against HMEC-1 cells depends on the number of methylene groups and, in particular, a minimal length of alkyl side chain is required for the $\mathrm{RB}$ cytotoxicity of both OMe and PivNH derivatives (14-16 and 20-22, Table 2). On the contrary, the antiplasmodial activity does not show any linear correlation with the length of the alkyl chain in both series, being anyway not dramatically affected (Table 2).

According to the above structure-activity relationships (SARs), compounds bearing ethyl side chain show a different activity profile: (i) the RA amide-derivative $\mathbf{1 7}$ is the most potent antiplasmodial agent of the series $\left(\mathrm{IC}_{50} 0.39 \mu \mathrm{M}\right.$ (D10) and
$0.58 \mu \mathrm{M}$ (W2), but it is also significantly cytotoxic ( $\left.\mathrm{IC}_{50} 1.60 \mu \mathrm{M}\right)$; (ii) its $\mathrm{RB}$ regioisomer $\mathbf{2 0}$ shows reduced antiplasmodial activity $\left(\mathrm{IC}_{50} 6.15 \mu \mathrm{M}\right.$ (D10) and $6.31 \mu \mathrm{M}$ (W2)) but it is not cytotoxic, and (iii) the RB methoxy-derivative $\mathbf{1 4}$ is still active as antiplasmodial at low micromolar concentration with $\mathrm{IC}_{50} 2.45 \mu \mathrm{M}$ and $2.37 \mu \mathrm{M}$ against D10 and W2 strains, respectively, without displaying any cytotoxicity.

In summary, some of the new synthetic derivatives showed interesting in vitro activities and, mainly, some structural requirements critical for both the antiplasmodial effect and cytotoxicity, have been evidenced.

\section{Computational studies}

In order to rationalize the SARs and to investigate the putative antimalarial mechanism of action of the new thiazinoquinones, the two couples of regioisomers with the highest difference in the antiplasmodial activity and the smallest structural variation (i.e., 12, 15 and 19, 22; Table 2), were subjected to an in-depth computational analysis (see Experimental section for details).

Firstly, we calculated the prevalent ionic forms at $\mathrm{pH} 7.2$ (cytoplasm) and pH 5.5 (P. falciparum food vacuole) (Table $2 \mathrm{SI} \dagger$ ). Then, in order to sample the conformational space of the compounds under investigation, a calculation protocol including a simulated annealing procedure followed by molecular mechanics (MM) energy minimization and semi-empirical PM7 full geometry optimization, was applied. Obtained conformers were ranked by their potential energy values and the global minimum conformer (GM) of each compound was selected as starting structure for subsequent calculations.

The mechanism of action of antimalarial quinones has been related to their redox properties, and, in particular, to the capacity to form toxic semiquinone radical species $\left(\mathbf{Q H}^{*}\right)$ through a one-electron reduction reaction. ${ }^{20}$ Indeed, the two-

Table 2 Effect of compounds 11-22 and on the growth of CQ-sensitive (D10) and CQ-resistant (W2) P. falciparum strains ${ }^{a}$. Cytoxicity against human microvascular endothelial (HMEC-1) cells<smiles>[R]C1=C([Y9](C)(C)C)C(=O)C2=C(C1=O)S(=O)(=O)CCN2</smiles>

\begin{tabular}{|c|c|c|c|c|c|c|c|c|c|c|c|}
\hline Comp. & $\mathrm{R}_{1}$ & $n$ & $\begin{array}{l}\text { D10 } \mathrm{IC}_{50}{ }^{b} \\
(\mu \mathrm{M})\end{array}$ & $\begin{array}{l}\text { W2 } \mathrm{IC}_{50}{ }^{b} \\
(\mu \mathrm{M})\end{array}$ & $\begin{array}{l}\text { HMEC-1 } \mathrm{IC}_{50}{ }^{b} \\
(\mu \mathrm{M})\end{array}$ & Comp. & $\mathrm{R}_{1}$ & $n$ & $\begin{array}{l}\text { D10 } \mathrm{IC}_{50}{ }^{b} \\
(\mu \mathrm{M})\end{array}$ & $\begin{array}{l}\text { W2 } \mathrm{IC}_{50}{ }^{b} \\
(\mu \mathrm{M})\end{array}$ & $\begin{array}{l}\text { HMEC-1 } \text { IC }_{50}{ }^{b} \\
(\mu \mathrm{M})\end{array}$ \\
\hline 11 & $\mathrm{OMe}$ & 1 & $\mathrm{NA}^{c}$ & $\mathrm{NA}^{c}$ & $\mathrm{NA}^{c}$ & 14 & $\mathrm{OMe}$ & 1 & $2.45 \pm 0.42$ & $2.37 \pm 0.42$ & $\mathrm{NA}^{c}$ \\
\hline 13 & $\mathrm{OMe}$ & 13 & $\mathrm{NA}^{c}$ & $\mathrm{NA}^{c}$ & $\mathrm{NA}^{c}$ & 16 & $\mathrm{OMe}$ & 13 & $1.73 \pm 0.93$ & $1.32 \pm 0.26$ & $4.41 \pm 1.25$ \\
\hline 17 & $\mathrm{NHCOC}\left(\mathrm{CH}_{3}\right)_{3}$ & 1 & $0.39 \pm 0.15$ & $0.58 \pm 0.12$ & $1.60 \pm 0.34$ & 20 & $\mathrm{NHCOC}\left(\mathrm{CH}_{3}\right)_{3}$ & 1 & $6.15 \pm 1.10$ & $6.31 \pm 2.33$ & $\mathrm{NA}^{c}$ \\
\hline 18 & $\mathrm{NHCOC}\left(\mathrm{CH}_{3}\right)_{3}$ & 4 & $1.56 \pm 0.12$ & $2.70 \pm 0.72$ & $0.90 \pm 0.11$ & 21 & $\mathrm{NHCOC}\left(\mathrm{CH}_{3}\right)_{3}$ & 4 & $6.93 \pm 0.24$ & $7.87 \pm 0.25$ & $\mathrm{NA}^{c}$ \\
\hline
\end{tabular}

${ }^{a}$ Chloroquine (CQ) has been considered as positive control (D10 $\mathrm{IC}_{50}=0.04 \pm 0.01 ; \mathrm{W} 2 \mathrm{IC}_{50}=0.54 \pm 0.28$; not cytotoxic). ${ }^{b}$ Data are the mean $\pm \mathrm{SD}$ of three different experiments in duplicate. ${ }^{c}$ NA: not active $\left(\mathrm{IC}_{50}>10 \mu \mathrm{M}\right.$ against $\mathrm{D} 10$ and $\mathrm{W} 2$ strains of $P$. falciparum and $\mathrm{IC}_{50}>100 \mu \mathrm{M}$ against HMEC-1). 


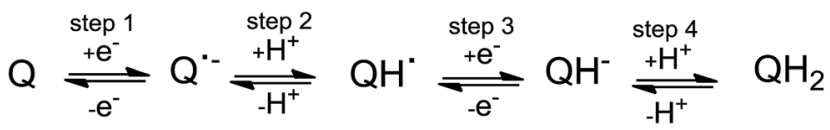

Scheme 2 Sequence of steps in quinone reduction pathway.

electron, two-proton, reduction pathway of quinones $(\mathbf{Q})$ to hydroquinones $\left(\mathbf{Q H}_{2}\right)$ involves a sequence of steps in which reversible one-electron reduction reactions are followed by proton uptake reactions producing the semiquinone species $\left(\mathbf{Q H}^{*}\right)$, as illustrated in Scheme $2 .^{21}$

On these bases, we investigated the redox properties of $\mathbf{1 2}$, 15,19 , and 22 , focusing on the ability to form the toxic semiquinone radical species. The putative reduction pathway of our new thiazinoquinones involves the formation of two possible semiquinone species $\left(\mathbf{Q H}_{\mathbf{i}}{ }^{\text {and }} \mathbf{Q} \mathbf{Q H}^{\cdot}\right.$ ii Fig. 3).

Thus, starting from the structure of the GM conformers of 12, 15, 19, and 22, the respective $\mathbf{Q}^{\cdot-}, \mathbf{Q H}^{\cdot}$, and $\mathbf{Q H}^{\cdot}{ }_{\text {ii }}$ radicals were generated and subjected to further semi-empirical (PM7) calculations to obtain a full geometry and energy optimization. The reaction enthalpies $\left(\mathrm{kcal} \mathrm{mol}^{-1}\right)$ for the formation of the two possible semiquinone radical species $\mathbf{Q H}_{\mathbf{i}}{ }_{\mathrm{i}}$ and $\mathbf{Q} \mathbf{H}_{\text {ii }}$ (i.e. steps 1 and 2, Scheme 2) were then calculated (Table 3). The obtained results highlighted that all compounds present a definite preference for the formation of the semiquinone species named $\mathbf{Q H}_{\mathbf{i}}^{\cdot}$ in Fig. $3\left(\Delta H_{\mathrm{f}(\mathbf{Q} \rightarrow \mathbf{Q H}}{ }^{\prime} \mathbf{i}\right)$ vs. $\Delta H_{\mathrm{f}(\mathbf{Q} \rightarrow \mathbf{Q H} \cdot \mathbf{i i})}$; Table 3). The higher stability of $\mathbf{Q H}_{\mathbf{i}}{ }$ with respect to $\mathbf{Q H}_{\mathbf{i i}}$ is likely due to the presence of an hydrogen bond between the reduced oxygen and the $\mathrm{SO}_{2}$ group (Fig. $1 \mathrm{SI}$ and $2 \mathrm{SI} \dagger$ ).

According to these results, for the $\mathbf{Q}, \mathbf{Q}^{\cdot-}$, and $\mathbf{Q H}_{\mathbf{i}}{ }^{\text {species of }}$ each compound, the energy of the frontier molecular orbitals

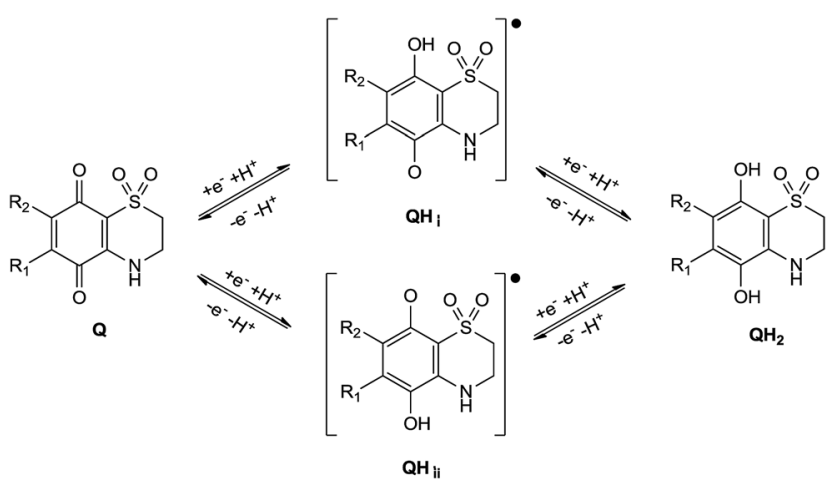

Fig. 3 Schematic representation of the putative thiazinoquinone reduction pathway. (highest occupied molecular orbital (HOMO), lowest unoccupied molecular orbital (LUMO), and singly-occupied molecular orbital (SOMO)) was calculated. Then, using these values, the redox capacities were assessed by calculating: (i) vertical ionization potential (IP), (ii) electron affinity (EA), ${ }^{22}$ (iii) electrophilicity index $(\omega)^{23}$ (see Experimental section for details). All the above data are reported in Table 4.

The whole of the data reported in Tables 3 and 4 evidenced a relationship between the ability of thiazinoquinones to form the $\mathbf{Q H}_{\mathbf{i}}{ }_{\mathrm{i}}$ radical species and their antiplasmodial activity. In particular, the regioisomers $\mathbf{1 5}$ and $\mathbf{1 9}$, active as antimalarials, showed lower reaction enthalpies for the first step of the reduction process (Scheme 2) with respect to the corresponding inactive regioisomers 12 and $22\left(\Delta H_{\mathrm{f}\left(\mathbf{Q} \rightarrow \mathbf{Q}^{-}\right)}\right)$; Table 3$)$. In addition, the $\mathbf{Q}$ species of $\mathbf{1 5}$ and $\mathbf{1 9}$ showed lower LUMO energy and higher $\omega$ values than those of $\mathbf{1 2}$ and 22, respectively (Table 4). Interestingly, the vertical IP and SOMO energy values indicate that the $\mathbf{Q}^{--}$species of the inactive regioisomer $\mathbf{2 2}$ tend to be re-oxidized to the parent quinone $\mathbf{Q}$ more than that of the active 19. The same is valid comparing 12 (inactive) and $\mathbf{1 5}$ (active) (Table 4). Although, in the case of 12 and 15, the difference is minimal, there is a larger difference in the sum of the reaction enthalpies of step 1 and 2 (Scheme 2) leading to the formation of $\mathbf{Q H}_{\mathbf{i}}\left(\Delta H_{\mathrm{f}(\mathbf{Q} \rightarrow \mathbf{Q H} \cdot \mathbf{i})}\right.$; Table 3).

Last but not least, we investigated if conformational parameters play a role in the redox properties of the inactive regioisomer 22 with respect to the active 19. Indeed, contrarily to 12 and 15 (Fig. 3SI†), the GM conformers of 19 and 22 differed significantly (Fig. 4A vs. B) and, in particular, presented a different conformation of the amide function and different intramolecular H-bond interactions. As evidenced in Fig. 4A, the intramolecular $\mathrm{H}$-bond between the amide nitrogen and the quinone oxygen favors the planarity of thiazoquinone ring of $\mathbf{1 9}$. On the contrary, as evidenced in Fig. $4 \mathrm{~B}$, due to the intramolecular $\mathrm{H}$-bond between the amide oxygen and the ring amine function, the thiazoquinone ring system of 22 significantly deviate from planarity.

In order to investigate if this is related to the lower propensity of $\mathbf{2 2}$ to undergo a one electron reduction with respect to $\mathbf{1 9}$ $\left(\Delta H_{\mathrm{f}\left(\mathbf{Q} \rightarrow \mathbf{Q}^{-}\right)}\right.$, Table $3 ; \omega$ of $\mathbf{Q}$, Table 4$)$, we selected the conformer of $\mathbf{2 2}$ having the same conformation of the amide substituent of the GM conformer of 19 (named 22B; Fig. 4C). It has to be underlined that conformer 22B is not a low energy conformer of 22, showing a $\Delta E$ from the GM conformer of 5.24 $\mathrm{kcal} \mathrm{mol}{ }^{-1}$, hence it was not included in our previous analysis. The redox properties of conformer 22B were calculated applying the same approach previously described. It resulted that,

Table 3 Reaction enthalpies of $12,15,19$, and 22 for the formation of the two possible semiquinone species reported in Fig. $3\left(\Delta H_{f} ; k^{\prime}\right.$ al mol $\left.{ }^{-1}\right)$

\begin{tabular}{|c|c|c|c|c|c|}
\hline Comp. & $\left(\mathbf{Q} \rightarrow \mathbf{Q}^{\cdot-}\right)$ & $\left(\mathbf{Q}^{\cdot-} \rightarrow \mathbf{Q H}_{\mathbf{i}}\right)$ & $\left(\mathbf{Q} \rightarrow \mathbf{Q H}_{\mathbf{i}}^{*}\right)$ & $\left(\mathbf{Q}^{\cdot-} \rightarrow \mathbf{Q H}_{\mathrm{ii}}^{\cdot}\right)$ & $\left(\mathbf{Q} \rightarrow \mathbf{Q H}_{\mathrm{ii}}\right)$ \\
\hline 12 & -60.38 & 53.00 & -7.38 & 53.91 & -6.47 \\
\hline 15 & -66.05 & 45.82 & -20.23 & 59.45 & -6.60 \\
\hline 22 & -50.68 & 38.20 & -12.48 & 46.99 & -3.69 \\
\hline
\end{tabular}


Table 4 PM7-calculated orbital energies (LUMO and SOMO), electrophilicity index ( $\omega)$, vertical ionization potential (IP) and vertical electron affinity (EA) for $Q, Q^{*-}, \mathrm{QH}^{*}$ i species of $12,15,19$, and 22

\begin{tabular}{|c|c|c|c|c|c|c|c|c|}
\hline \multirow[b]{2}{*}{ Comp. } & \multicolumn{2}{|l|}{$\mathbf{Q}$} & \multicolumn{2}{|l|}{$\mathbf{Q}^{\cdot-}$} & \multicolumn{4}{|l|}{$\mathrm{QH}_{\mathrm{i}}$} \\
\hline & $E_{\text {LUMO }}{ }^{a}$ & $\omega$ & $E_{\text {SOMO }}{ }^{a}$ & Vertical IP ${ }^{a}$ & $E_{\text {SОмо }}{ }^{a}$ & Vertical IP ${ }^{a}$ & Vertical EA ${ }^{a}$ & $\omega$ \\
\hline 15 & -1.791 & 2.080 & -3.928 & 2.465 & -7.969 & 6.607 & 2.694 & 2.763 \\
\hline 19 & -1.598 & 1.931 & -3.859 & 2.361 & -7.968 & 6.391 & 2.863 & 3.034 \\
\hline 22 & -1.189 & 1.711 & -3.215 & 1.749 & -7.685 & 6.084 & 2.655 & 2.784 \\
\hline
\end{tabular}

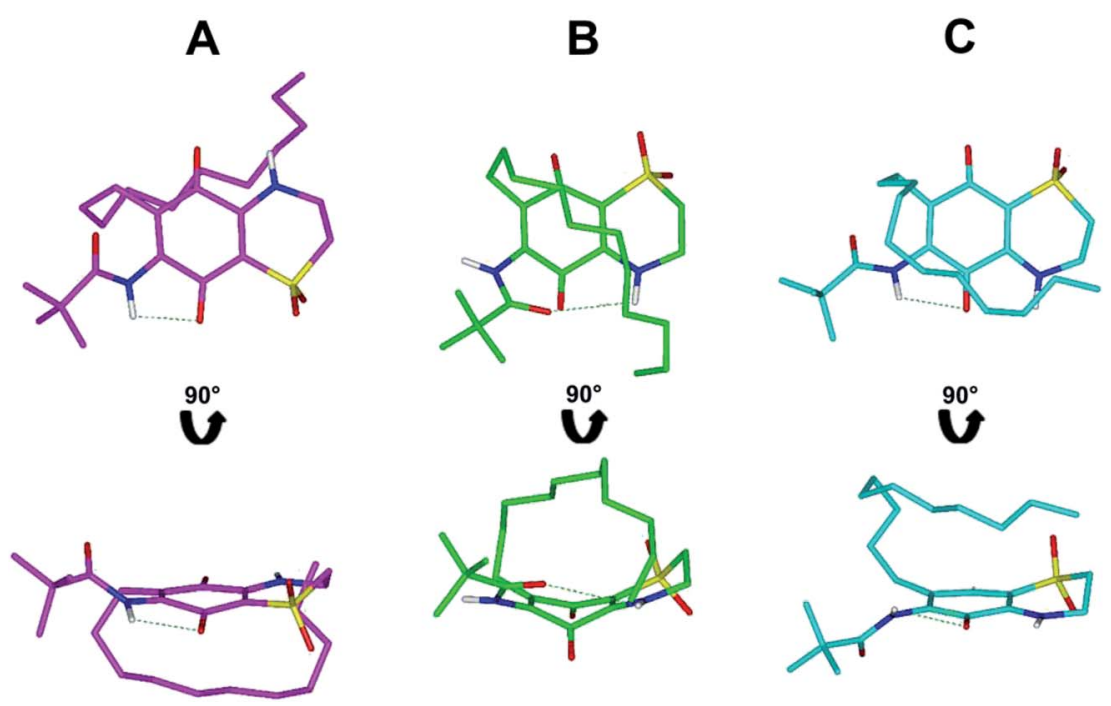

Fig. 4 PM7 GM conformer of 19 (magenta; A); PM7 GM conformer of 22 (green; B) and PM7 conformer 22B (cyan; C). Front view (top) and longitudinal view (bottom). The ligands are colored by atom type $(\mathrm{O}=\mathrm{red}, \mathrm{N}=$ blue, $\mathrm{S}=$ yellow and $\mathrm{H}=$ white). $\mathrm{H}$-bonds between the amide function and the thiazinoquinone ring are highlighted by green dashed lines. Hydrogens are omitted for the sake of clarity with the exception of those involved in $\mathrm{H}$-bonds.

compared to the GM conformer of 22, conformer 22B presents: (i) lower reaction enthalpies for both the first step of the reduction process $\left(\Delta H_{\mathrm{f}\left(\mathbf{Q} \rightarrow \mathbf{Q}^{-}\right)}\right)$and the formation of $\mathbf{Q} \mathbf{H}_{\mathbf{i}}$ $\left(\Delta H_{\mathrm{f}(\mathbf{Q} \rightarrow \mathbf{Q H} \cdot \mathbf{i})}\right)$ (Table $5 v s$. Table 3$)$, (ii) lower LUMO energy and higher $\omega$ values of the $\mathbf{Q}$ species (Table $6 v s$. Table 4). Moreover, the SOMO energy and vertical IP values indicate that the $\mathbf{Q}^{\cdot-}$ species of conformer 22B tend to be re-oxidized to the parent quinone $\mathbf{Q}$ less than that of the GM conformer (Table 6 vs. Table 4). These results indicate that the thiazinoquinone ring system planarity (Fig. 4C vs. Fig.4B) plays a crucial role in the reductive activation leading to the formation of $\mathbf{Q H}^{\cdot}$ radical.

Thus, according to these calculations, in the case of $\mathbf{1 2}$ and 15, the position of the OMe substituent by itself affects the redox properties of the compound, without any significant change in the conformational properties of the thiazinoquinone system. On the contrary, in the case of the PivNH substituent, the regiochemistry of $\mathbf{2 2}$ leads to a different conformational behavior compared to $\mathbf{1 9}$, and this, in turn, determines its lower propensity to undergo the one electron reduction.
Finally, the $\log D$ values of all compounds were calculated $(c \log D$ Table 7$)$ to investigate a possible role of cellular pharmacokinetic parameters in the antiplasmodial activity of thiazinoquinones. Results evidenced that there is no correlation between the $c \log D$ values and the antiplasmodial activity (Table 7 vs. Table 2).

Indeed, as reported in the previous paragraph, there is no linear correlation between the length of the alkyl chain and the antiplasmodial activity, with the most active compound 17 presenting just an ethyl chain (Table 2). It is worth to be mentioned that, on the contrary, in naphthoquinone-like systems a linear alkyl chain with a minimal length of 6

Table 5 Reaction Enthalpies of conformer 22B for the formation of the two possible semiquinone species reported in Fig. $3\left(\Delta H_{f} ; \mathrm{kcal}\right.$ $\mathrm{mol}^{-1}$ )

\begin{tabular}{lllll}
$\left(\mathbf{Q} \rightarrow \mathbf{Q}^{*}\right)$ & $\left(\mathbf{Q}^{\cdot}-\rightarrow \mathbf{Q H}_{\mathbf{i}}^{*}\right)$ & $\left(\mathbf{Q} \rightarrow \mathbf{Q H}_{\mathbf{i}}\right)$ & $\left(\mathbf{Q}^{-}-\rightarrow \mathbf{Q H}_{\mathrm{ii}}\right)$ & $\left(\mathbf{Q} \rightarrow \mathbf{Q H}_{\text {ii }}\right)$ \\
\hline-67.56 & 48.01 & -19.55 & 54.60 & -12.96
\end{tabular}


Table 6 PM7-calculated orbital energies (LUMO and SOMO), electrophilicity index ( $\omega)$, vertical ionization potential (IP) and vertical electron affinity (EA) for $\mathrm{Q}, \mathrm{Q}^{--}, \mathrm{QH}^{\cdot}$ i species of conformer $22 \mathrm{~B}$

\begin{tabular}{|c|c|c|c|c|c|c|c|}
\hline \multicolumn{2}{|l|}{$\mathbf{Q}$} & \multicolumn{2}{|l|}{$\mathbf{Q}^{\cdot-}$} & \multicolumn{4}{|l|}{$\mathrm{QH}_{\mathrm{i}}$} \\
\hline$E_{\mathrm{LUMO}}{ }^{a}$ & $\omega$ & $E_{\text {Sомо }}{ }^{a}$ & Vertical IP ${ }^{a}$ & $E_{\text {SOMO }}{ }^{a}$ & Vertical IP ${ }^{a}$ & Vertical EA ${ }^{a}$ & $\omega$ \\
\hline-1.843 & 2.098 & -4.056 & 2.486 & -7.955 & 6.431 & 2.911 & 3.099 \\
\hline
\end{tabular}

Table $7 \quad c \log D$ values of compounds 11-22

\begin{tabular}{lrlr}
\hline Comp. & $c \log D$ & Comp. & $c \log D$ \\
\hline $\mathbf{1 1}$ & -0.25 & $\mathbf{1 7}$ & -0.19 \\
$\mathbf{1 2}$ & 2.87 & $\mathbf{1 8}$ & 1.40 \\
$\mathbf{1 3}$ & 5.71 & $\mathbf{1 9}$ & 4.70 \\
$\mathbf{1 4}$ & -0.25 & 20 & -0.19 \\
$\mathbf{1 5}$ & 2.87 & $\mathbf{2 1}$ & 1.40 \\
$\mathbf{1 6}$ & 5.71 & 22 & 4.70 \\
\hline
\end{tabular}

carbons is required to inhibit ubiquinone enzymes, such as, the cytochrome bc1 complex and the type II NADH dehydrogenase (PfNDH2). ${ }^{24,25}$

In summary, the results of our computational analysis strongly suggest that the higher antiplasmodial activity of thiazinoquinones 15 and 19 with respect to 12 and 22, is related to their greater ability to form a stable semiquinone species. In this way they could act, like other antimalarial quinones, by shuttling single electrons from reduced systems to key oxidants such as hemoglobin-associated or free Fe(III)-protoporphyrin IX. ${ }^{26-28}$ This could not only contribute to the production of reactive oxygen species through Fenton chemistry but also prevent both the digestion of hemoglobin and the formation of hemozoin, so that the redox equilibrium is affected leading to the death of the parasite.

\section{Electrochemical studies}

The electrochemical response of thiazinoquinones was investigated, in order to reveal such relationship with their antiplasmodial effects observed in vitro. In view of the poor water solubility of the studied compounds, solid state electrochemistry was performed following the voltammetry of microparticles technique (VMP). This methodology, developed by Scholz et al. ${ }^{29-31}$ enables to determine the voltammetric response of sparingly soluble solid materials in contact with suitable electrolytes. VMP has been previously applied for studying the composition of solid flavonoids and indigoids, ${ }^{32-34}$ among others, and monitoring the antioxidative properties of vegetables. ${ }^{35}$

Two series of experiments were carried out upon attachment of microsamples of thiazinoquinones to glassy carbon electrodes.

Direct electrochemistry. The "direct" electrochemistry of the solid compounds in contact with phosphate buffer saline electrolyte at biological $\mathrm{pH}$ was obtained in order to characterize differences in the redox behavior of the different compounds.
Fig. 5 compares the initial cathodic scan cyclic voltammograms of 19, 22, 17, and 20-modified glassy carbon electrodes immersed into PBS at $\mathrm{pH}$ 7.4. In the case of 19, in the initial cathodic scan (Fig. 5a), reduction peaks appear at $-0.61\left(\mathrm{C}_{1}\right)$ and $-0.94\left(\mathrm{C}_{2}\right) \mathrm{V}$. These signal are coupled, in the subsequent anodic scan, with a weak shoulder at $-0.76 \mathrm{~V}\left(\mathrm{~A}_{2}\right)$ and a welldefined oxidation peak at $-0.07 \mathrm{~V}\left(\mathrm{~A}_{1}\right)$. A similar voltammetry was displayed by compound 22 (Fig. 5b). In the case of 17 (Fig. 5c), however, the peak $\mathrm{A}_{1}$ is overlapped with an additional oxidation wave at $+0.08 \mathrm{~V}\left(\mathrm{~A}_{3}\right)$ whereas, at more positive potentials, an anodic peak at $+0.89 \mathrm{~V}\left(\mathrm{~A}_{4}\right)$ appears, followed, in the subsequent cathodic scan, by a weak shoulder at $+0.65 \mathrm{~V}$ $\left(\mathrm{C}_{4}\right)$. The $\mathrm{A}_{4} / \mathrm{C}_{4}$ couple also appears in initial anodic scan voltammograms, thus denoting that it is attributable to the oxidation of the parent compound rather than an electrochemically generated oxidized form. In the subsequent cathodic scan, the peak $\mathrm{C}_{1}$ is significantly lowered and preceded by a signal at $-0.30 \mathrm{~V}\left(\mathrm{C}_{3}\right)$. The peak $\mathrm{C}_{3}$ can be assigned to the cathodic counterpart of the peak $A_{3}$, which is enhanced at the expense of the peak $A_{1}$ upon repetitive cycling the potential scan. The $\mathrm{A}_{4} / \mathrm{C}_{4}$ couple was absent in the voltammetric response of 20 (Fig. $5 \mathrm{~d}$ ), consisting of the $\mathrm{C}_{1} / \mathrm{A}_{1}$ couple accompanied by a well-defined peak $\mathrm{C}_{2}$ and the $\mathrm{C}_{3} / \mathrm{A}_{3}$ couple. The voltammetric response of all the other compounds consisted of similar features to those of the above types, with variations around $200 \mathrm{mV}$ in the peak potentials of the $\mathrm{C}_{1} / \mathrm{A}_{1}$ couple, as summarized in Table 8.

The above voltammetry can be described on assuming that, in solid state, proton insertion/issue must accompany electron ingress/loss for reasons of charge conservation. ${ }^{29,30}$ Accordingly, and assuming that no dissolution processes are involved in electrochemical turnovers, different electrochemical pathways would be superimposed. Scheme 3 shows the proposed electrochemical pathway illustrated for the case of compound $\mathbf{1 7}$.

The process $\mathrm{C}_{1} / \mathrm{A}_{1}$ appears at the potentials typical of anthraquinone and naphtoquinone compounds $\mathrm{s}^{32-34}$ and can be unambiguously attributed to the reduction of the quinone unit to the corresponding diol. The anodic process $\mathrm{A}_{4}$ can be assigned to the oxidation of the $\mathrm{NH}$ function so that the corresponding quinone would be reduced similarly to the parent compound giving rise to the $\mathrm{C}_{3} / \mathrm{A}_{3}$ couple. Finally, the cathodic process $\mathrm{C}_{2}$ should be attributed to the reduction of the $-\mathrm{SO}_{2}$ group to $-\mathrm{SO}$.

Examination of voltammetric data reveals that the significant differences observed in the antiplasmodial activity of thiazinoquinones are not directly reflected in their solid-state 


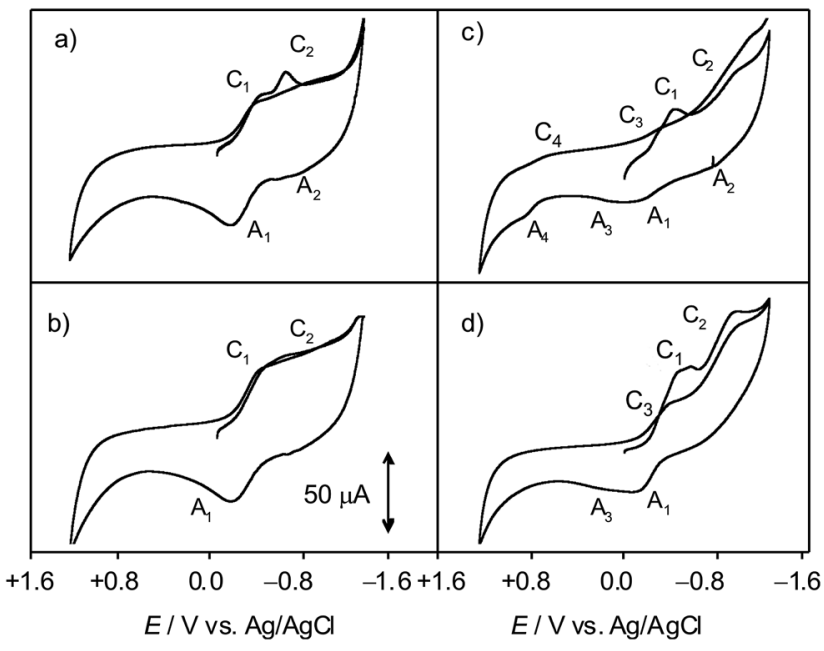

Fig. 5 Cyclic voltammograms of (a) 19, (b) 22, (c) 17 and, (d) 20-modified glassy carbon electrodes immersed into $0.10 \mathrm{M} \mathrm{PBS}$ at $\mathrm{pH}$ 7.4. Potential scan initiated at $0.0 \mathrm{~V}$ in the negative direction; potential scan rate $50 \mathrm{mV} \mathrm{s}^{-1}$.

Table 8 Peak potential data (in $\mathrm{mV}$ vs. $\mathrm{Ag} / \mathrm{AgCl}$ ) for the studied compounds recorded in cyclic voltammograms of compound films on glassy carbon electrode immersed into 0.10 M PBS at pH 7.4. Potential scan rate $50 \mathrm{mV} \mathrm{s}^{-1}$

\begin{tabular}{lllll}
\hline Comp. & $\mathrm{C}_{1} / \mathrm{A}_{1}$ & $\mathrm{C}_{2} / \mathrm{A}_{2}$ & $\mathrm{C}_{3} / \mathrm{A}_{3}$ & $\mathrm{C}_{4} / \mathrm{A}_{4}$ \\
\hline $\mathbf{1 1}$ & $-330 /-190$ & $-820 /$ & & $/+640$ \\
$\mathbf{1 4}$ & $-290 /-80$ & & & $/+650$ \\
$\mathbf{1 5}$ & $-550 /-150$ & $-1000 /$ & $-600 /$ & $+920 /$ \\
$\mathbf{1 6}$ & $-620 /-110$ & $-1020 /$ & $-420 / 0$ & $+910 /+640$ \\
$\mathbf{1 7}$ & $-450 /-100$ & $-980 /-760$ & $-300 /+80$ & $+650 /+890$ \\
$\mathbf{1 8}$ & $-580 /-90$ & $-1000 /$ & $-370 /-90$ & $+840 /$ \\
$\mathbf{1 9}$ & $-610 /-70$ & $-940 /-760$ & $-390 /$ & \\
$\mathbf{2 0}$ & $-440 /-90$ & $-990 /$ & $-580 /$ & \\
$\mathbf{2 1}$ & $-500 /-40$ & $-850 /$ & $-330 /+60$ & \\
$\mathbf{2 2}$ & $-400 /-110$ & $-900 /$ & & \\
& & & &
\end{tabular}

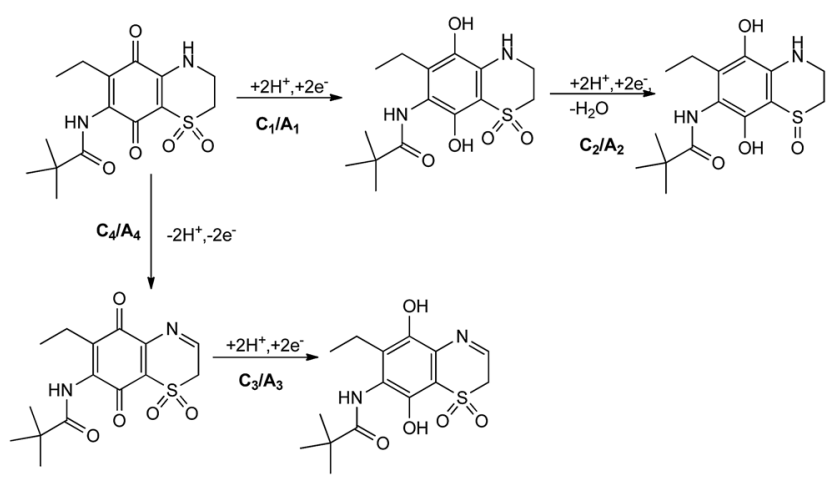

Scheme 3 Electrochemical processes involved in the solid state voltammetry of 17 .

electrochemistry, offering similar patterns for all compounds. This can be attributed to the non-reversible nature of the involved electrochemical processes, denoted by the large anodic-to-cathodic peak potential separations, associated, at least partly, to the kinetic constraints in the ingress/issue of protons to/from the lattice as demanded by the solid state electrochemistry of such compounds. Then, their apparent equilibrium potentials for the reduction from quinones to hydroquinones $\left(\mathbf{Q} \rightarrow \mathbf{Q H}_{\mathbf{2}}\right.$ ), do not correlate with their antiplasmodial activity.

Interaction with heme. Electrochemical studies can provide relevant information with regard to heme-protein adsorption, denaturalization, heme release, and catalysis. ${ }^{36}$ On this basis, we have recently developed an electrochemical assay of hemebinding molecules for the screening of antimalarial drugs acting via the hemozoin mechanism which can be performed in both lipophilic and aqueous environment. ${ }^{37}$ This method provides high sensitivity with amounts of compounds to be tested in the microgram-nanogram range and allows compounds interacting significantly with heme to be identified as potential antimalarial agent. In a second series of experiments, electrochemical measurements were performed with the electrodes immersed into $\mathrm{Fe}(\mathrm{III})$-heme solutions. In these conditions, the voltammetric response of the studied compounds experiences significant changes, as shown in Fig. 6, where cyclic voltammograms of 19- and 22-modified glassy carbon electrodes immersed into $3 \mu \mathrm{M} \mathrm{Fe}(\mathrm{III})$-heme plus $0.10 \mathrm{M}$ PBS at pH 7.4 are shown.

Upon comparing these voltammograms with those recorded in absence of $\mathrm{Fe}(\mathrm{III})$-heme (Fig. 5), one can see that for 22, the reduction peak $\mathrm{C}_{1}$ is catalytically enhanced while its anodic counterpart $A_{1}$ vanishes (Fig. $5 b$ vs. $6 \mathrm{~b}$ ). Considering literature on quinone electrochemistry, ${ }^{38,39}$ the voltammetry results of compound 22 could be rationalized upon assuming that the reduced quinone $\mathbf{Q H}_{2}$ reacts with $\mathrm{Fe}(\mathrm{III})$-heme regenerating the parent quinone (Q) (eqn (1) and (2), \{\}$_{\text {solid }}$ denotes solid phases).

$$
\begin{aligned}
\{\mathbf{Q}\}_{\text {solid }} & +2 \mathrm{H}^{+}(\mathrm{aq})+2 \mathrm{e}^{-} \rightarrow\{\mathbf{Q H}\}_{\text {solid }} \\
\left\{\mathbf{Q H}_{2}\right\}_{\text {solid }} & +2 \mathrm{Fe}(\mathrm{III})-\text { heme } \rightarrow\{\mathbf{Q}\}_{\text {solid }} \\
& +2 \mathrm{Fe}(\mathrm{II})-\text { heme }+2 \mathrm{H}^{+}(\mathrm{aq})
\end{aligned}
$$

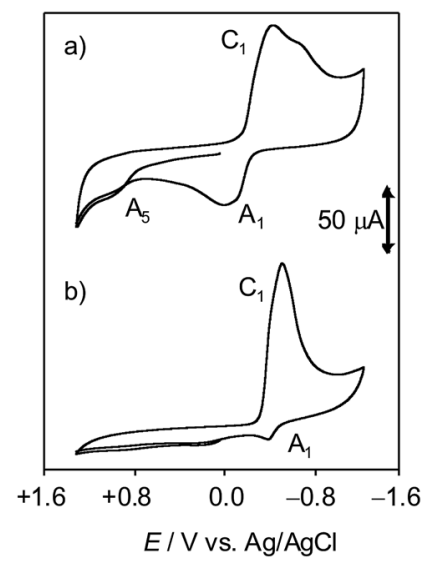

Fig. 6 Cyclic voltammograms of (a) 19-, (b) 22-modified glassy carbon electrodes immersed into $3 \mu \mathrm{M} \mathrm{Fe(II)-heme} \mathrm{plus} \mathrm{0.10} \mathrm{M} \mathrm{PBS} \mathrm{at} \mathrm{pH} \mathrm{7.4.}$ Potential scan rate $50 \mathrm{mV} \mathrm{s}^{-1}$. 
As a result, the peak $\mathrm{C}_{1}$, corresponding to $\mathbf{Q}$ reduction to $\mathbf{Q H}_{2}$, is catalytically enhanced while the anodic signal $\mathrm{A}_{1}$, corresponding to the oxidation of hydroquinone $\mathbf{Q} \mathbf{H}_{2}$, vanishes (Fig. 6b).

In contrast, for 19 (Fig. 5a vs. 6a), there appears peak splitting in the $\mathrm{C}_{1}$ signal while the anodic wave $\mathrm{A}_{1}$ remains welldefined and a new peak $\left(\mathrm{A}_{5}\right)$ at $c a$. $+0.90 \mathrm{~V}$ appears in both negative- and positive-going scan voltammograms at potentials similar to those of peak $\mathrm{A}_{4}$ (see Table 8). In this case, the splitting of peak $\mathrm{C}_{1}$ is likely due to the formation of the $\mathbf{Q H}$ species (intermediate in the reduction of $\mathbf{Q}$, eqn (3)), then captured in a stable surface adduct with Fe(III)-heme (eqn (4), \{\}$_{\text {surf }}$ surface-confined adduct species); in other words, in the case of 19, either two-electrons (eqn (1)) and one-electron (eqn (3)) reduction is observed:

$$
\begin{gathered}
\{\mathbf{Q}\}_{\text {solid }}+\mathrm{H}^{+}(\mathrm{aq})+\mathrm{e}^{-} \rightarrow\left\{\mathbf{Q H}^{\bullet}\right\}_{\text {solid }} \\
\left\{\mathbf{Q H}^{\bullet}\right\}_{\text {solid }}+\mathrm{Fe}(\mathrm{III}) \text {-heme } \rightarrow\left\{\mathbf{Q H}^{\bullet} \cdot \mathrm{Fe}(\mathrm{III})-\text { heme }\right\}_{\text {surf }}
\end{gathered}
$$

This would also be consistent with the appearance in the voltammogram of 19 (Fig. 6a) of the new anodic signal $\left(A_{5}\right)$ at positive potentials corresponding to the $-\mathrm{NH}$-centered oxidation (see Scheme 3) of the Fe(III)-heme-adduct.

Accordingly, the differences observed in the voltammetric response of compounds 19 and 22 could be interpreted by the coexistence of two competing pathways, the predominance of one or another pathway being dependent, among other factors, on the stability of the protonated semiquinone form $\mathbf{Q H} \mathbf{H}^{*}$. This, in turn, is related to the one electron-accepting properties of $\mathbf{Q}$ and the IP of QH* Then, compound 22, for which theoretical calculations provide an electron accepting propensity of $\mathbf{Q}$ (LUMO energy) smaller than for $\mathbf{1 9}$ and a lower IP of $\mathbf{Q H}^{*}$, would mainly follow the pathway represented by eqn (1) and (2), while, for compound 19, the pathway represented by eqn (3) and (4) would contribute significantly to its voltammetric response, thus determining the peak splitting in the cathodic process.

To further investigate this issue, we increased the concentration of $\mathrm{Fe}$ (III)-heme to $10 \mu \mathrm{M}$, so that the above compoundcentered electrochemistry is superimposed to iron-centered processes. Fig. 7 compares the square wave voltammograms recorded in a $10 \mu \mathrm{M}$ solution of Fe(III)-heme in 0.10 M PBS at (a) unmodified glassy carbon electrode, (b) 22-, (c) 19- and (d) 17-modified electrode. In Fig. 7a, a well-defined peak at $-0.35 \mathrm{~V}$ $\left(\mathrm{C}_{\mathrm{H}}\right)$ can be observed, due to an essentially reversible oneelectron transfer process, corresponding to the reduction of $\mathrm{Fe}(\mathrm{III})$-heme to $\mathrm{Fe}(\mathrm{II})$-heme, in agreement with literature. ${ }^{37} \mathrm{~A}$ quite identical voltammetry response was obtained at electrodes modified with the inactive compound 22 (see Fig. $7 \mathrm{~b} v s$. $7 \mathrm{a}$. In contrast, at electrodes modified with 19 , an active antiplasmodial compound, the peak $\mathrm{C}_{\mathrm{H}}$ is shifted and split in two separate peaks (labeled as $\mathrm{C}_{\mathrm{H}}{ }^{\prime}$ and $\mathrm{C}_{\mathrm{H}}{ }^{\prime \prime}$ ) and accompanied by the peak $\mathrm{C}_{1}$ at $-0.60 \mathrm{~V}$ (Fig. $7 \mathrm{c}$ ). In the case of 17 , the most active antiplasmodial compound in the series, the two components of the peak $\mathrm{C}_{\mathrm{H}}$ become largely separated so that the second one appears superimposed to the peak $\mathrm{C}_{1}$ (Fig. 7d). The splitting of the $\mathrm{C}_{\mathrm{H}}$ peak could be rationalized in terms of the superposition

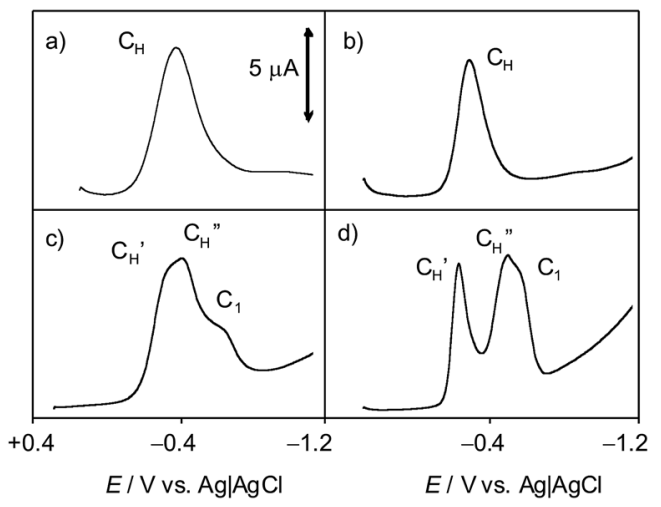

Fig. 7 Square wave voltammograms of: (a) $10 \mu \mathrm{M}$ solution of Fe(III)heme in 0.10 M PBS at unmodified glassy carbon electrode; (b) 22-; (c) 19-; (d) 17-modified electrode immersed into $10 \mu \mathrm{M}$ Fe(III)-heme plus $0.10 \mathrm{M}$ PBS. Potential scan initiated at $+0.25 \mathrm{~V}$ in the negative direction. Potential step increment $4 \mathrm{mV}$; square wave amplitude $25 \mathrm{mV}$; frequency $5 \mathrm{~Hz}$.

of the direct reduction of $\mathrm{Fe}(\mathrm{III})$-heme to $\mathrm{Fe}(\mathrm{II})$-heme (eqn (5)) to the reduction of surface-confined Fe-heme adducts as described in eqn (6):

$$
\begin{gathered}
\mathrm{Fe}(\mathrm{III})-\text { heme }+\mathrm{e}^{-} \rightarrow \mathrm{Fe}(\mathrm{II}) \text {-heme } \\
\left\{\mathbf{Q H}^{\cdot} \cdot \mathrm{Fe} \text { (III)-heme }\right\}_{\text {surf }}+\mathrm{e}^{-} \rightarrow\{\mathrm{Fe}(\mathrm{II}) \text {-heme } \cdots \mathbf{Q H}\}_{\text {surf }}
\end{gathered}
$$

In summary, the splitting experienced by the peak $\mathrm{C}_{\mathrm{H}}$, observed in several ligand-modified electrodes in contact with $\mathrm{Fe}(\mathrm{III})$-heme solutions, can be indicative of a strong interaction between the compound and Fe(III)-heme. This interaction could be one of the preconditions for displaying antimalarial activity, as previously reported, ${ }^{37}$ being the basis for the activity of a variety of antiplasmodial molecules which, in this manner, interfere with the parasite-specific heme detoxification pathway. Remarkably, in the case of compounds 15-22, sharp differences between the intensity of this interaction were found, as shown in Fig. 7 and 8. Consistently with the foregoing set of considerations, the largest peak splitting was observed for highly active compounds 17 (Fig. 7d) and 15 (Fig. 8e). In general, the absolute value of the difference, $\left|\Delta E_{\mathrm{p}}^{\mathrm{VMP}}\right|$, between the peak potentials relative to the 'free' and 'complexed' $\mathrm{Fe}(\mathrm{III})$-heme reduction signals $\left(\mathrm{C}_{\mathrm{H}}\right)$ measured in VMP experiments can be taken as indicative of the strength of $\mathrm{Fe}(\mathrm{III})$-heme compound interaction. ${ }^{37}$ As reported in Table 9, the $\left|\Delta E_{\mathrm{p}}^{\mathrm{VMP}}\right|$ values measured for compounds 15-22 are in good agreement with their antiplasmodial activity against D10 and W2 strains.

\section{$\beta$-Hematin formation inhibitory activity assay}

In order to further explore the interaction of our thiazinoquinones with Fe(III)-heme, we performed the $\beta$-hematin inhibitory activity assay on the three amide derivatives 17, 20, and 22, using chloroquine (CQ) as reference compound. $\beta$-Hematin 


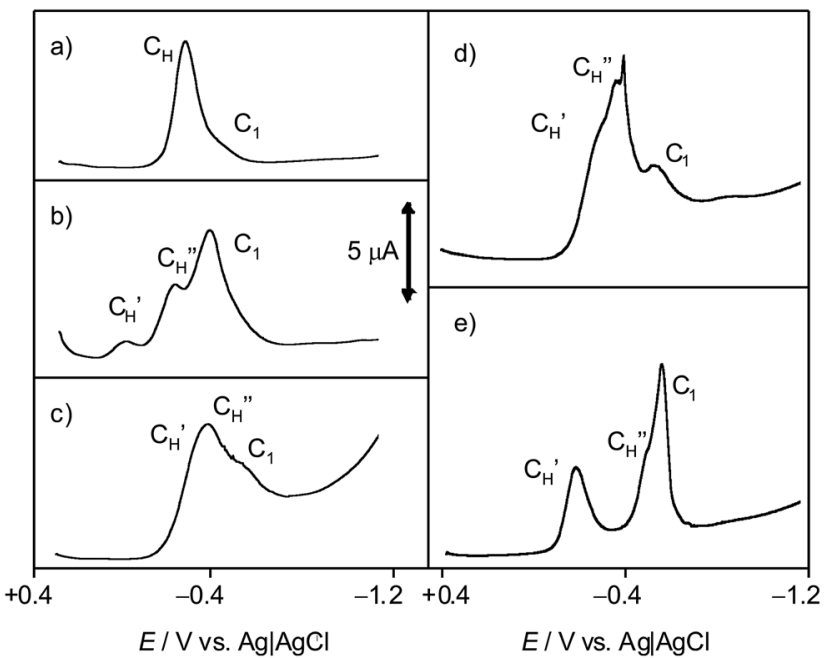

Fig. 8 Square wave voltammograms of $10 \mu \mathrm{M}$ solution of Fe(III)-heme in $0.10 \mathrm{M}$ PBS at glassy carbon electrodes modified with: (a) 20; (b) 18; (c) 16, (d) 21; (e) 15. Potential scan initiated at $+0.25 \mathrm{~V}$ in the negative direction. Potential step increment $4 \mathrm{mV}$; square wave amplitude $25 \mathrm{mV}$; frequency $5 \mathrm{~Hz}$.

Table 9 Electrochemical activity of compounds 15-22, expressed as $\left|\Delta E_{\mathrm{p}}^{\mathrm{VMP}}\right|$ vs. antiplasmodial activity observed in vitro

\begin{tabular}{lll}
\hline Comp. & Antiplasmodial activity & $\left|\Delta E_{\mathrm{p}}^{\mathrm{VMP}}\right|(\mathrm{mV})$ \\
\hline $\mathbf{1 5}$ & Very active & 280 \\
16 & Active & 120 \\
17 & Very active & 330 \\
18 & Active & 180 \\
19 & Active & 200 \\
20 & Poorly active & 150 \\
21 & Poorly active & 160 \\
22 & Inactive & 70
\end{tabular}

formation was assayed by a spectrophotometric microassay BHIA ( $\beta$-hematin inhibitory assay) as previously reported. ${ }^{40}$ Results are reported in Fig. 9 and Table 3SI. $\dagger$

As reported in Fig. 9, none of the tested compounds resulted significantly active at the tested concentrations, although they

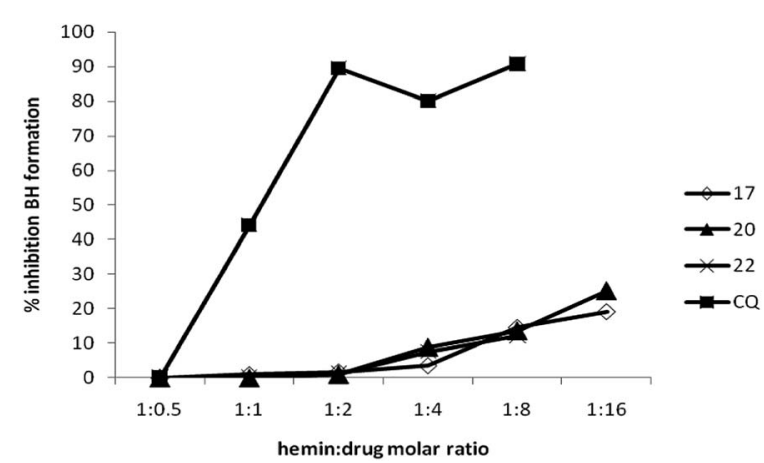

Fig. $9 \beta$-Hematin inhibitory activity assay of compounds 17,20 and 22 in comparison with chloroquine (CQ). are characterized by diverse antiplasmodial activities, 17 being more active than 20, and $\mathbf{2 2}$ being inactive (Table 2). The lack of activity observed for all compounds in the $\beta$-hematin inhibition assay demonstrates that the parent quinone $\mathbf{Q}$ (oxidized form, Scheme 2) does not interact with $\mathrm{Fe}(\mathrm{III})$-heme. This is in agreement with the results of computational and electrochemical studies, which indicate that the antiplasmodial activity is related to the formation of a stable and redox active complex between the one-electron-reduced semiquinone radical $\mathbf{Q H} \mathbf{H}^{\cdot}$ and $\mathrm{Fe}(\mathrm{III})$-heme.

\section{Experimental section}

\section{Chemistry}

$N$-(2,5-Dimethoxyphenyl)pivalamide (24). To $3 \mathrm{~g}(19.60 \mathrm{mmol})$ of 23, dissolved in $25 \mathrm{~mL}$ of dichloromethane-water $1: 1,5 \mathrm{~g}$ ( $47 \mathrm{mmol}$ ) of $\mathrm{Na}_{2} \mathrm{CO}_{3}$ were added under stirring. Then, $2.5 \mathrm{~mL}$ of pivaloylchloride $(0.02 \mathrm{mmol})$ were added dropwise and the mixture was stirred for 3 hours at room temperature (the end of the reaction was checked by TLC, eluent: hexane-ethyl acetate $7: 3$ ). The dark liquid was then poured into cold water and extracted three times with dichloromethane. The combined organic layers were washed with brine, dried with sodium sulfate and filtered; solvent removal under reduced pressure gave 24 (4.38 g, yield 95\%) sufficiently pure for the following reaction. ${ }^{1} \mathrm{H}$ NMR $200 \mathrm{MHz}\left(\mathrm{CDCl}_{3}\right): \delta 1.31\left(9 \mathrm{H}, \mathrm{s},-\mathrm{C}\left(\mathrm{CH}_{3}\right)_{3}\right)$; $3.77\left(3 \mathrm{H}, \mathrm{s},-\mathrm{OCH}_{3}\right) ; 3.84\left(3 \mathrm{H}, \mathrm{s},-\mathrm{OCH}_{3}\right) ; 6.55(1 \mathrm{H}, \mathrm{dd}, J=8.8$, $2.8 \mathrm{~Hz}, \mathrm{H}-4)$; $6.78(1 \mathrm{H}, \mathrm{d}, J=8.8 \mathrm{~Hz}, \mathrm{H}-3) ; 8.17(1 \mathrm{H}, \mathrm{d}, J=2.8 \mathrm{~Hz}$, $\mathrm{H}-6)$.

$\boldsymbol{N}$-(2-Formyl-3,6-dimethoxyphenyl)pivalamide (25). To $4.00 \mathrm{~g}$ (16.88 mmol) of 24 dissolved in $60 \mathrm{~mL}$ of anhydrous THF, $32.0 \mathrm{~mL}$ of a $n$-BuLi $1.6 \mathrm{M}$ solution $(50.64 \mathrm{mmol})$ were added, under argon atmosphere at $0{ }^{\circ} \mathrm{C}$; the mixture was stirred for $2 \mathrm{~h}$. Then, $5.12 \mathrm{~mL}$ of DMF (65.84 $\mathrm{mmol})$ were added dropwise and the mixture was left under stirring for $16 \mathrm{~h}$ (the end of the reaction was checked by TLC, eluent: hexane-ethyl acetate $9: 1)$. The mixture was poured into cold water $(150 \mathrm{~mL})$ and extracted three times with ethyl acetate. The combined organic layers were washed with brine, dried over sodium sulfate, and filtered. The solvent removal under reduced pressure gave a crude product $(4.1 \mathrm{~g}$ ) which was purified by chromatography on 'acidic' silica gel (eluent: hexane-ethyl acetate $9: 1$ ) to give pure 25 (3.064 g, $11.56 \mathrm{mmol}$, yield 68.5\%). ${ }^{1} \mathrm{H}$ NMR $300 \mathrm{MHZ}$ $\left(\mathrm{CDCl}_{3}\right): \delta 1.32\left(9 \mathrm{H}, \mathrm{s},-\mathrm{C}\left(\mathrm{CH}_{3}\right)_{3}\right) ; 3.83\left(3 \mathrm{H}, \mathrm{s},-\mathrm{OCH}_{3}\right) ; 3.85(3 \mathrm{H}$, $\left.\mathrm{s},-\mathrm{OCH}_{3}\right) ; 6.74(1 \mathrm{H}, \mathrm{d}, J=9.3 \mathrm{~Hz}, \mathrm{H}-5) ; 7.12(1 \mathrm{H}, \mathrm{d}, J=9.3 \mathrm{~Hz}$, $\mathrm{H}-4)$; 9.20 (1H, bs, NH); $10.38(1 \mathrm{H}, \mathrm{s},-\mathrm{CHO})$.

$\boldsymbol{N}$-(2-(1-Hydroxyalkyl)-3,6-dimethoxyphenyl)pivalamides (26ac). To a suspension of $73 \mathrm{mg}$ of $\mathrm{Mg}$ powder $(3 \mathrm{mmol})$ in $2 \mathrm{~mL}$ of anhydrous diethyl ether, $2.28 \mathrm{mmol}$ of iodoalkane $(0.14 \mathrm{~mL}$ of iodomethane, $0.44 \mathrm{~mL}$ of iodobutane, and $2.05 \mathrm{~mL}$ of iododecane, respectively) in $5 \mathrm{~mL}$ of anhydrous diethyl ether were added slowly under stirring at room temperature. After completion, the reaction mixture was refluxed for $1 \mathrm{~h}$ and then a solution of 25 (150 mg, $0.57 \mathrm{mmol})$ in anhydrous diethyl ether $(10 \mathrm{~mL})$ was added dropwise. The reaction was refluxed for 4 hours (the end of the reaction was checked by TLC, eluent: chloroform-ethyl acetate 9:1) and quenched with $6 \mathrm{~mL}$ of 
saturated $\mathrm{NH}_{4} \mathrm{Cl}$. The mixture was poured into water $(20 \mathrm{~mL})$ and extracted three times with ethyl acetate. The combined organic layers were washed with brine, dried over sodium sulfate, and filtered; solvent removal under reduced pressure gave products 26a (158.6 mg, 99\%), 26b (182.5 mg, 99\%) as a colorless crystals sufficiently pure for the following reaction and a crude product $(400.0 \mathrm{mg})$, which was purified by chromatography on silica gel (eluent: hexane-ethyl acetate $6: 4$ ) to give pure 26c (174.3 mg, 75\%). ${ }^{1} \mathrm{H}$ NMR $300 \mathrm{MHZ}\left(\mathrm{CDCl}_{3}\right)$ 26a: $\delta 1.32$ $\left(9 \mathrm{H}, \mathrm{s},-\mathrm{C}\left(\mathrm{CH}_{3}\right)_{3}\right) ; 1.58\left(3 \mathrm{H}, \mathrm{d}, J=6.6 \mathrm{~Hz},-\mathrm{CHOHCH}_{3}\right) ; 3.65(1 \mathrm{H}$, $\mathrm{d}, J=8.7 \mathrm{~Hz},-\mathrm{OH}) ; 3.75\left(3 \mathrm{H}, \mathrm{s},-\mathrm{OCH}_{3}\right) ; 3.83\left(3 \mathrm{H}, \mathrm{s},-\mathrm{OCH}_{3}\right)$; $4.96(1 \mathrm{H}, \mathrm{m},-\mathrm{CHOHCH}) ; 6.75(2 \mathrm{H}, \mathrm{s}, \mathrm{H}-4$ and $\mathrm{H}-5) ; 7.32(1 \mathrm{H}$, bs, NH). ${ }^{1} \mathrm{H}$ NMR $300 \mathrm{MHZ}\left(\mathrm{CDCl}_{3}\right)$ 26b: $\delta 0.85(3 \mathrm{H}, \mathrm{t}, J=6.8 \mathrm{~Hz}$, $\left.-\left(\mathrm{CH}_{2}\right)_{3} \mathrm{CH}_{3}\right)$; 1.15-1.44 (13H, $-\mathrm{CH}_{2}\left(\mathrm{CH}_{2}\right)_{2} \mathrm{CH}_{3}$ and $\left.-\mathrm{C}\left(\mathrm{CH}_{3}\right)_{3}\right)$; 1.74-1.97 (2H, m, - $\left.\mathrm{CHOHCH}_{2}-\right)$; $3.55(1 \mathrm{H}, \mathrm{bs},-\mathrm{OH}) ; 3.74(3 \mathrm{H}, \mathrm{s}$, $\left.-\mathrm{OCH}_{3}\right) ; 3.78\left(3 \mathrm{H}, \mathrm{s},-\mathrm{OCH}_{3}\right) ; 4.80(1 \mathrm{H}, \mathrm{m},-\mathrm{CHOH}-) ; 6.73(2 \mathrm{H}, \mathrm{s}$, $\mathrm{H}-4$ and $\mathrm{H}-5) ; 7.42(1 \mathrm{H}, \mathrm{bs}, \mathrm{NH}) .{ }^{1} \mathrm{H}$ NMR $300 \mathrm{MHZ}\left(\mathrm{CDCl}_{3}\right) 26 \mathrm{c}: \delta$ $0.87\left(3 \mathrm{H}, \mathrm{t}, \mathrm{J}=6.5 \mathrm{~Hz},-\left(\mathrm{CH}_{2}\right)_{9} \mathrm{CH}_{3}\right) ; 1.14-1.30\left(16 \mathrm{H},-\mathrm{CH}_{2}\left(\mathrm{CH}_{2}\right)_{8^{-}}\right.$ $\left.\mathrm{CH}_{3}\right) ; 1.32\left(9 \mathrm{H}, \mathrm{s},-\mathrm{C}\left(\mathrm{CH}_{3}\right)_{3}\right) ; 1.77-1.99\left(2 \mathrm{H}, \mathrm{m},-\mathrm{CHOHCH}_{2}-\right) ; 3.30$ $(1 \mathrm{H}, \mathrm{bs},-\mathrm{OH}) ; 3.75\left(3 \mathrm{H}, \mathrm{s},-\mathrm{OCH}_{3}\right) ; 3.81\left(3 \mathrm{H}, \mathrm{s},-\mathrm{OCH}_{3}\right) ; 4.79(1 \mathrm{H}$, m, - $\mathrm{CHOH}-)$; 6.75 (2H, s, H-4 and $\mathrm{H}-5)$; 7.34 (1H, bs, NH).

$\mathrm{N}$-(2-Alkyl-3,6-dimethoxyphenyl)pivalamides (27a-c). To a suspension of $38 \mathrm{mg}$ of $10 \%$ Pd-on-charcoal in EtOH $(5 \mathrm{~mL})$ and $\mathrm{HCl}$ conc. ( $0.2 \mathrm{~mL}) 0.31 \mathrm{mmol}$ of each compound $26 \mathrm{a}-\mathbf{c}(87 \mathrm{mg}$ of $26 \mathrm{a}, 100 \mathrm{mg}$ of $26 \mathbf{b}, 126 \mathrm{mg}$ of $26 \mathbf{c}$ ) were added under atmosphere of $\mathrm{H}_{2}$ (balloon) at room temperature. After stirring for 2.5 hours (the end of the reaction was checked by TLC, eluent: hexane-ethyl acetate $7: 3$ ), the hydrogen atmosphere was replaced by a argon atmosphere and then the mixture was filtered through a fluted filter paper washing the catalyst several times with EtOH (total volume $100 \mathrm{~mL}$ ). The filtrate was concentrated under reduced pressure and $20 \mathrm{~mL}$ of saturated $\mathrm{NaHCO}_{3}$ solution were added to the residue; the resulting solution was then extracted three times with ethyl ether. The organic phase was washed with brine, dried over sodium sulfate, and filtered. The solvent removal under reduced pressure afforded $27 \mathbf{a}$ (80 mg, 97\%), 27b (91.5 mg, 96\%) and 27c (112 mg, 92\%) sufficiently pure for the following reaction. ${ }^{1} \mathrm{H}$ NMR $300 \mathrm{MHZ}\left(\mathrm{CDCl}_{3}\right)$ 27a: $\delta 1.08\left(3 \mathrm{H}, \mathrm{t}, J=7.5 \mathrm{~Hz},-\mathrm{CH}_{2} \mathrm{CH}_{3}\right)$; $1.34\left(9 \mathrm{H}, \mathrm{s},-\mathrm{C}\left(\mathrm{CH}_{3}\right)_{3}\right) ; 2.58\left(2 \mathrm{H}, \mathrm{q}, J=7.5 \mathrm{~Hz},-\mathrm{CH}_{2} \mathrm{CH}_{3}\right) ; 3.74$ $\left(3 \mathrm{H}, \mathrm{s},-\mathrm{OCH}_{3}\right) ; 3.78\left(3 \mathrm{H}, \mathrm{s},-\mathrm{OCH}_{3}\right) ; 6.67(1 \mathrm{H}, \mathrm{d}, J=9.0 \mathrm{~Hz}, \mathrm{H}-5)$; $6.73(1 \mathrm{H}, \mathrm{d}, J=9.0 \mathrm{~Hz}, \mathrm{H}-4) ; 6.87(1 \mathrm{H}, \mathrm{bs}, \mathrm{NH}) .{ }^{1} \mathrm{H}$ NMR 200 $\mathrm{MHz}\left(\mathrm{CDCl}_{3}\right)$ 27b: $\delta 0.87\left(3 \mathrm{H}, \mathrm{t}, J=7.5 \mathrm{~Hz},-\left(\mathrm{CH}_{2}\right)_{4} \mathrm{CH}_{3}\right) ; 1.18-$ $1.49\left(15 \mathrm{H}, \mathrm{s},-\mathrm{CH}_{2}\left(\mathrm{CH}_{2}\right)_{3} \mathrm{CH}_{3}\right.$ and $\left.-\mathrm{C}\left(\mathrm{CH}_{3}\right)_{3}\right) ; 2.54(2 \mathrm{H}, \mathrm{m}$, $\left.-\mathrm{CH}_{2}\left(\mathrm{CH}_{2}\right)_{3} \mathrm{CH}_{3}\right) ; 3.74\left(3 \mathrm{H}, \mathrm{s},-\mathrm{OCH}_{3}\right) ; 3.76\left(3 \mathrm{H}, \mathrm{s},-\mathrm{OCH}_{3}\right) ; 6.68$ $(1 \mathrm{H}, \mathrm{d}, J=9.0 \mathrm{~Hz}, \mathrm{H}-5) ; 6.74(1 \mathrm{H}, \mathrm{d}, J=9.0 \mathrm{~Hz}, \mathrm{H}-4) ; 6.87(1 \mathrm{H}$, bs, $\mathrm{NH}) .{ }^{1} \mathrm{H}$ NMR $300 \mathrm{MHZ}\left(\mathrm{CDCl}_{3}\right) 27 \mathrm{c}: \delta 0.88(3 \mathrm{H}, \mathrm{t}, J=7.5 \mathrm{~Hz}$, $\left.-\left(\mathrm{CH}_{2}\right)_{10} \mathrm{CH}_{3}\right) ; 1.25-1.45\left(27 \mathrm{H}, \mathrm{s},-\mathrm{CH}_{2}\left(\mathrm{CH}_{2}\right)_{9} \mathrm{CH}_{3}\right.$ and $\left.-\mathrm{C}\left(\mathrm{CH}_{3}\right)_{3}\right)$; $2.54\left(2 \mathrm{H}, \mathrm{m},-\mathrm{CH}_{2}\left(\mathrm{CH}_{2}\right)_{9} \mathrm{CH}_{3}\right) ; 3.74\left(3 \mathrm{H}, \mathrm{s},-\mathrm{OCH}_{3}\right) ; 3.77(3 \mathrm{H}, \mathrm{s}$, $\left.-\mathrm{OCH}_{3}\right) ; 6.68(1 \mathrm{H}, \mathrm{d}, J=8.7 \mathrm{~Hz}, \mathrm{H}-5) ; 6.73(1 \mathrm{H}, \mathrm{d}, J=8.7 \mathrm{~Hz}, \mathrm{H}-$ 4); $6.86(1 \mathrm{H}, \mathrm{bs}, \mathrm{NH})$.

$\mathrm{N}$-(2-Alkyl-3,6-dioxocyclohexa-1,4-dienyl)pivalamides (28a-c). $0.91 \mathrm{mmol}$ of each compound $27 \mathrm{a}-\mathrm{c}$ (240 $\mathrm{mg}$ of $27 \mathrm{a}, 280 \mathrm{mg}$ of $27 \mathbf{b}, 356 \mathrm{mg}$ of $27 \mathrm{c}$ ) dissolved in $50 \mathrm{~mL}$ of acetonitrile were added dropwise to a solution of CAN $(1.5 \mathrm{~g}, 2.72 \mathrm{mmol})$ in water $(16 \mathrm{~mL})$ at rt. The mixture was stirred for 5 minutes at room temperature (the end of the reaction was checked by TLC, eluent: chloroform- ethyl acetate $7: 3$ ). The orange liquid was then poured into 100 $\mathrm{mL}$ of cold water and extracted three times with ethyl acetate. The combined organic layers were washed with brine, dried over sodium sulfate, and filtered. The solvent removal under reduced pressure afforded 28a (210 mg, 99\%), 28b (250 mg, 99\%) and 28c (326 mg, 99\%) sufficiently pure for the following reaction. ${ }^{1} \mathrm{H}$ NMR $300 \mathrm{MHZ}\left(\mathrm{CDCl}_{3}\right)$ 28a: $\delta 1.07\left(3 \mathrm{H}, \mathrm{t}, J=7.5 \mathrm{~Hz},-\mathrm{CH}_{2} \mathrm{CH}_{3}\right)$; $1.32\left(9 \mathrm{H}, \mathrm{s},-\mathrm{C}\left(\mathrm{CH}_{3}\right)_{3}\right) ; 2.47\left(2 \mathrm{H}, \mathrm{q}, J=7.5 \mathrm{~Hz},-\mathrm{CH}_{2} \mathrm{CH}_{3}\right) ; 6.73$ $(1 \mathrm{H}, \mathrm{d}, J=9.9 \mathrm{~Hz}, \mathrm{H}-5) ; 6.77(1 \mathrm{H}, \mathrm{d}, J=9.9 \mathrm{~Hz}, \mathrm{H}-4) ; 7.66(1 \mathrm{H}, \mathrm{bs}$, $\mathrm{NH}) .{ }^{1} \mathrm{H}$ NMR $400 \mathrm{MHz}\left(\mathrm{CDCl}_{3}\right) 28 \mathrm{~b}: \delta 0.86(3 \mathrm{H}, \mathrm{t}, J=7.0 \mathrm{~Hz}$, $\left.-\left(\mathrm{CH}_{2}\right)_{4} \mathrm{CH}_{3}\right)$; 1.25-1.45 (15H, m, $-\mathrm{CH}_{2}\left(\mathrm{CH}_{2}\right)_{3} \mathrm{CH}_{3}$ and $\left.-\mathrm{C}\left(\mathrm{CH}_{3}\right)_{3}\right)$; $2.48\left(2 \mathrm{H}, \mathrm{m},-\mathrm{CH}_{2}\left(\mathrm{CH}_{2}\right)_{3} \mathrm{CH}_{3}\right) ; 6.73(1 \mathrm{H}, \mathrm{d}, J=9.9 \mathrm{~Hz}, \mathrm{H}-5) ; 6.76$ $(1 \mathrm{H}, \mathrm{d}, J=9.9 \mathrm{~Hz}, \mathrm{H}-4) ; 7.62(1 \mathrm{H}, \mathrm{bs}, \mathrm{NH}) .{ }^{1} \mathrm{H}$ NMR $300 \mathrm{MHZ}$ $\left(\mathrm{CDCl}_{3}\right) 28 \mathrm{c}: \delta 0.86\left(3 \mathrm{H}, \mathrm{t}, J=6.6 \mathrm{~Hz},-\left(\mathrm{CH}_{2}\right)_{10} \mathrm{CH}_{3}\right) ; 1.15-1.42(27 \mathrm{H}$, $\mathrm{m},-\mathrm{CH}_{2}\left(\mathrm{CH}_{2}\right)_{9} \mathrm{CH}_{3}$ and $\left.-\mathrm{C}\left(\mathrm{CH}_{3}\right)_{3}\right) ; 2.47\left(2 \mathrm{H}, \mathrm{m},-\mathrm{CH}_{2}\left(\mathrm{CH}_{2}\right)_{9} \mathrm{CH}_{3}\right)$; $6.72(1 \mathrm{H}, \mathrm{d}, J=9.9 \mathrm{~Hz}, \mathrm{H}-5) ; 6.76(1 \mathrm{H}, \mathrm{d}, J=9.9 \mathrm{~Hz}, \mathrm{H}-4) ; 7.62(1 \mathrm{H}$, bs, $\mathrm{NH})$.

$N$-(6-Alkyl-1,1,5,8-tetraoxo-3,4,5,8-tetrahydro-2H-benzo $[b][1,4]-$ thiazin-7-yl)pivalamides (17-19) and $N$-(7-alkyl-1,1,5,8-tetraoxo3,4,5,8-tetrahydro-2H-benzo $[b][1,4]$ thiazin-6-yl)pivalamides (20-22). $0.53 \mathrm{mmol}$ of each quinone $28 \mathrm{a}-\mathrm{c}$ (125 $\mathrm{mg}$ of $28 \mathrm{a}, 147 \mathrm{mg}$ of $28 \mathrm{~b}$, $192 \mathrm{mg}$ of 28c) were dissolved in $7 \mathrm{~mL}$ of a mixture of $\mathrm{EtOH}-\mathrm{CH}_{3} \mathrm{CN}$ $1: 1$ and heated in a water bath under stirring; then, a solution of hypotaurine ( $173 \mathrm{mg}, 1.59 \mathrm{mmol}$ ) in $8 \mathrm{~mL}$ of water was added in portions. The mixture was stirred for $24 \mathrm{~h}$ at room temperature (the end of the reaction was checked by TLC, eluent: ethyl acetatehexane $10: 3$ ). The yellow solution became orange/red. Most of the ethanol was removed in vacuo and the residue was poured into water. The mixture was extracted with ethyl acetate (three times) and the organic phase was washed with brine, dried over sodium sulfate, and filtered. The solvent removal under reduced pressure afforded in each case a crude mixture of the a couple of isomers, $157 \mathrm{mg}$ of $\mathbf{1 7 / 2 0}, 159 \mathrm{mg}$ of $\mathbf{1 8} / \mathbf{2 1}$, and $270 \mathrm{mg}$ of $\mathbf{1 9} / \mathbf{2 2}$. The crude mixture of $\mathbf{1 7 / 2 0}$ isomers was separated and purified by HPLC on a $\mathrm{SiO}_{2}$ column (Luna $3 \mu \mathrm{m}, 150 \times 4.60 \mathrm{~mm}$ ) eluting with EtOAchexane $7: 3(\mathrm{v} / \mathrm{v})$, affording pure compounds 17 (19.5 mg, $0.057 \mathrm{mmol}, 11 \%$ ) and 20 (36.4 mg, $0.11 \mathrm{mmol}, 21 \%$ ). Mixtures of isomers 18-21 and 19-22 were separated in the same conditions and yielded pure compounds 18 (11.7 mg, $0.029 \mathrm{mmol}, 6 \%), 21$ (24.3 mg, $0.059 \mathrm{mmol}, 11 \%), 19$ (16.9 mg, $0.036 \mathrm{mmol}, 7 \%$ ) and 22 (54.1 mg, $0.12 \mathrm{mmol}, 23 \%$ ) (see Tables 1 and $1 \mathrm{SI} \dagger$ ).

\section{Parasite growth and drug susceptibility assay}

The CQS (D10) and the CQR (W2) strains of P. falciparum were sustained in vitro as described by Trager and Jensen. ${ }^{\mathbf{1 1}}$ Parasites were maintained at 5\% hematocrit (human type A-positive red blood cells) in RPMI 1640 (EuroClone, Celbio) medium with the addition of 1\% AlbuMax (Invitrogen, Milan, Italy), 0.01\% hypoxanthine, $20 \mathrm{mM}$ HEPES, and $2 \mathrm{mM}$ glutamine. All cultures were maintained at $37{ }^{\circ} \mathrm{C}$ in a standard gas mixture consisting of $1 \%$ $\mathrm{O}_{2}, 5 \% \mathrm{CO}_{2}$, and $94 \% \mathrm{~N}_{2}$. Compounds were dissolved in DMSO and then diluted with medium to achieve the required concentrations (final DMSO concentration $<1 \%$, which is nontoxic to the parasite). Drugs were placed in 96 well flat-bottom microplates (COSTAR) and serial dilutions made. Asynchronous cultures with parasitemia of $1-1.5 \%$ and $1 \%$ final hematocrit were aliquoted 
into the plates and incubated for $72 \mathrm{~h}$ at $37^{\circ} \mathrm{C}$. Parasite growth was determined spectrophotometrically $\left(\mathrm{OD}_{650}\right)$ by measuring the activity of the parasite lactate dehydrogenase ( $\mathrm{pLDH})$, according to a modified version of Makler's method in control and drug-treated cultures. ${ }^{42}$ Antiplasmodial activity is expressed as the $50 \%$ inhibitory concentrations $\left(\mathrm{IC}_{50}\right)$. Each $\mathrm{IC}_{50}$ value is the mean \pm standard deviation of at least three separate experiments performed in duplicate.

\section{BHIA assay}

Hemin dissolved in DMSO $(0.4 \mu \mathrm{mol}$ per well $)$ was distributed in 96-well microplates. Chloroquine or the tested compounds, dissolved in water or DMSO, respectively, were added in doses ranging from 0.5 to 16 molar equivalents to hemin. In control wells, water or DMSO were added maintaining in each well the same DMSO : $\mathrm{H}_{2} \mathrm{O}$ ratio of $1: 1$ in a final volume of $100 \mu \mathrm{L}$. $\beta$-Hematin formation was initiated by the addition of $100 \mu \mathrm{L}$ of $8 \mathrm{M}$ acetate buffer ( $\mathrm{pH}$ 5.0). Plates were incubated at $37^{\circ} \mathrm{C}$ for $18 \mathrm{~h}$ to allow for complete reaction. The amount of $\beta$-hematin formed was determined by measuring the absorbance at $405 \mathrm{~nm}$ using a microtiter plate reader. The results are the mean of two experiments in duplicate. ${ }^{40}$

\section{Cytotoxicity assay}

The long-term human microvascular endothelial cell line (HMEC-1) immortalized by SV 40 large $T$ antigen $^{\mathbf{4 3}}$ was maintained in MCDB 131 medium (Invitrogen, Milan, Italy) supplemented with $10 \%$ fetal calf serum (HyClone, Celbio, Milan, Italy), $10 \mathrm{ng} \mathrm{mL} \mathrm{m}^{-1}$ of epidermal growth factor (Chemicon), $1 \mu \mathrm{g}$ $\mathrm{mL}^{-1}$ of hydrocortisone, $2 \mathrm{mM}$ glutamine, $100 \mathrm{U} \mathrm{mL}^{-1}$ of penicillin, $100 \mu \mathrm{g} \mathrm{mL} \mathrm{m}^{-1}$ of streptomycin, and $20 \mathrm{mM}$ Hepes buffer (EuroClone). Unless stated otherwise, all reagents were from Sigma Italia, Milan, Italy. For the cytotoxicity assays, cells were treated with serial dilutions of test compounds for $72 \mathrm{~h}$ and cell proliferation evaluated using the MTT assay already described. ${ }^{44}$ The results are expressed as $\mathrm{IC}_{50}$, which is the dose of compound necessary to inhibit cell growth by $50 \%$. All the tests were performed in duplicate at least three times.

\section{Molecular modeling studies}

Molecular modeling calculations were performed on SGI Origin 200 8XR12000 and E4 Server Twin $2 \times$ Dual Xeon-5520, equipped with two nodes. Each node: $2 \times$ Intel ${ }^{\circledR}$ Xeon ${ }^{\circledR}$ QuadCore E5520-2.26Ghz, 36 GB RAM. The molecular modeling graphics were carried out on SGI Octane 2 workstations.

Conformational property analysis. Apparent $\mathrm{p} K_{\mathrm{a}}$ and $\log D$ values of new thiazinoquinone compounds were calculated by using ACD/Percepta software. ${ }^{45}$ Accordingly, percentage of neutral/ionized forms were computed at $\mathrm{pH} 7.2$ (cytoplasmic $\mathrm{pH}$ value) and 5.5 ( $\mathrm{p} f$ food vacuole $\mathrm{pH}$ ) using the Henderson-Hasselbalch equation.

The new thiazinoquinone compounds 12, 15, 19 and 22 were built, taking into account the prevalent ionic forms at the considered different $\mathrm{pH}$ values, using the Insight 2005 Builder module (Accelrys Software Inc., San Diego). Atomic potentials and charges were assigned using the CFF91 force field. ${ }^{46}$
The conformational space of the compounds was sampled through 200 cycles of Simulated Annealing $(\varepsilon=1)$. In simulated annealing, the temperature is altered in time increments from an initial temperature to a final temperature by adjusting the kinetic energy of the structure (by rescaling the velocities of the atoms). The following protocol was applied: the system was heated up to $1000 \mathrm{~K}$ over $2000 \mathrm{fs}$ (time step $=3.0 \mathrm{fs}$ ); the temperature of $1000 \mathrm{~K}$ was applied to the system for $2000 \mathrm{fs}$ (time step $=3.0 \mathrm{fs}$ ) with the aim of surmounting torsional barriers; successively, temperature was linearly reduced to $300 \mathrm{~K}$ in $1000 \mathrm{fs}$ (time step = $1.0 \mathrm{fs}$ ). Resulting conformations were then subjected to molecular mechanic (MM) energy minimization within Insight 2005 Discover module (CFF91 force field; $\varepsilon=1$ ) until the maximum RMS derivative was less than $0.001 \mathrm{kcal}^{-1}$, using Conjugate Gradient $\mathrm{t}^{47}$ as minimization algorithm. MM conformers were then subjected to a full geometry optimization by sem-iempirical calculations, using the quantum mechanical method PM7 in the Mopac2012 package $^{48}$ and EF (eigenvector following routine) ${ }^{49}$ as geometry optimization algorithm. GNORM value was set to 0.01 . To reach a full geometry optimization the criteria for terminating all optimizations was increased by a factor of 100, using the keyword PRECISE. Resulting conformers were ranked by their potential energy values (i.e., $\Delta E$ from the global energy minimum). Finally, the conformers of 19 and 22 within 5 kcal $\mathrm{mol}^{-1}$ from the global minimum $\left(\Delta E_{\mathrm{GM}} \leq 5 \mathrm{kcal} \mathrm{mol}^{-1}\right)$ were analyzed and grouped into conformational families according to the amide conformation. The occurrence rates and $\Delta E_{\mathrm{GM}}$ range for each conformational family were calculated.

\section{Redox capacity analysis}

Starting from the structure of the GM conformers, the redox states $\mathbf{Q}^{\cdot-}, \mathbf{Q H}_{\mathbf{i}}^{\cdot}$ and $\mathbf{Q} \mathbf{H}_{\mathbf{i i}}$ were generated and used as starting structures for further semi-empirical (PM7) calculations. In view of the fact that the $\mathbf{Q}^{-}, \mathbf{Q H}_{\mathbf{i}}$ and $\mathbf{Q H}_{\mathbf{i i}}$ are radical species characterized by just one unpaired electron, the unrestricted Hartree-Fock method (UHF, PM7 method, Mopac2012) was used and the multiplicity was set to doublet. Moreover, EF (eigenvector following routine) as geometry optimization algorithm was used and GNORM value was set to 0.01 . To reach a full geometry optimization the criteria for terminating all optimizations was increased by a factor of 100, using the keyword PRECISE. Finally, to analyze the charge distribution and the spin density, the keywords BONDS and LARGE were used. The same protocol was performed also for the lowest energy PM7 conformer of 22 with the amide conformation of $\mathbf{1 9 .}$

For each considered redox state, were calculated: (i) the heat of formation $\left(\mathrm{H}_{\mathrm{f}}\right)$ and (ii) the energy of the frontier molecular orbitals (HOMO, LUMO, and SOMO). Then, using these values, the redox capacities were assessed calculating: (i) the electrophilicity index $(\omega)$, (ii) the vertical ionization potential (IP) and electron affinity (EA) and (iii) the reaction enthalpies $\left(\mathrm{kcal} \mathrm{mol}^{-1}\right)$ for electron/proton transfer (i.e. $\Delta H_{\mathrm{f}\left(\mathbf{Q} \rightarrow \mathbf{Q}^{-}\right)}: H_{\mathrm{f}\left(\mathbf{Q}^{-}\right)}-H_{\mathrm{f}(\mathbf{Q})}$; $\Delta H_{\mathrm{f}\left(\mathbf{Q}_{-\rightarrow}^{-} \mathbf{Q H}^{*}\right)}: H_{\mathrm{f}\left(\mathbf{Q H}^{*}\right)}-H_{\mathrm{f}\left(\mathbf{Q}^{-}\right)}$and $\left.\Delta H_{\mathrm{f}\left(\mathbf{Q} \rightarrow \mathbf{Q H}^{*}\right)}: H_{\mathrm{f}\left(\mathbf{Q H}^{*}\right)}-H_{\mathrm{f}(\mathbf{Q})}\right)$. In particular, the electrophilicity index $(\omega)$ was calculated following the expression $\omega=\left(\mu^{2} / 2 \eta\right)$, where $\mu$ is the chemical potential 
given by $\mu=-(\mathrm{IP}+\mathrm{EA}) / 2$ and $\eta$ is the chemical hardness given by $\eta=\left(\right.$ IP - EA). ${ }^{50}$ The vertical ionization potential (IP) and the vertical electron affinity (EA) were calculated from the energy of the LUMO of the nonradical cations and from the energy of HOMO of the nonradical anions in the geometry of the radicals, respectively. At this purpose, a single-point PM7 calculation (1SCF) was performed on the nonradical cations and anions of the obtained species $\mathbf{Q}^{--}$and $\mathbf{Q} \mathbf{H}_{\mathbf{i} \cdot}{ }^{22}$ Finally, gas phase reaction enthalpy calculations for electron attachment were accomplished by determining $\Delta H$ of the reaction $\mathrm{Y}+\mathrm{e}^{-} \rightarrow \mathrm{Y}^{-}$that is, $\Delta H=$ $H_{\mathrm{f}}\left(\mathrm{Y}^{-}\right)-H_{\mathrm{f}}(\mathrm{Y})$, where $\mathrm{Y}$ is $\mathbf{Q}$ or $\mathbf{Q H}^{\cdot}$ and $H_{\mathrm{f}}$ is the calculated heat of formation. Reaction enthalpies for proton attachment were calculated by determining $\Delta H$ of the reaction $\mathrm{Y}+\mathrm{H}^{+} \rightarrow \mathrm{YH}$ that is $\Delta H=H_{\mathrm{f}}(\mathrm{YH})-H_{\mathrm{f}}(\mathrm{Y})$, where $\mathrm{Y}$ is $\mathbf{Q}^{\cdot-}$ or $\mathbf{Q} \mathbf{H}^{-} .^{51}$

\section{Electrochemistry}

Experiments were performed at $298 \pm 1 \mathrm{~K}$ in a conventional three-electrode cell with $\mathrm{CH}$ 660I equipment. A BAS MF2012 glassy carbon working electrode (GCE) (geometrical area $0.071 \mathrm{~cm}^{2}$ ), a platinum wire auxiliary electrode and an $\mathrm{Ag} / \mathrm{AgCl}$ ( $3 \mathrm{M} \mathrm{NaCl}$ ) reference electrode were used. Films of the studied compounds on glassy carbon electrode were prepared by pippeting a drop of their suspensions in ethanol on an agate mortar and allowing the contact with the surface of the GCE during $30 \mathrm{~s}$, further rinsing the surface of the electrode with ethanol and water, successively. The voltammetric response of such modified electrodes was studied upon immersion into $0.10 \mathrm{M}$ aqueous phosphate buffer saline (PBS) at $\mathrm{pH}$ 7.4, previously dearated by bubbling Ar during $15 \mathrm{~min}$.

\section{Conclusions}

As a whole, our studies on thiazinoquinone compounds 11-22, prepared using marine natural products as lead structures, could represent a reliable groundwork for the development of new antimalarial agents. In particular, important structural requirements for antiplasmodial and cytotoxic activities have been evidenced and rationalized trough computational and experimental studies. The regiochemistry of the dioxothiazine ring and the nature of the substituent on the quinone ring both play a crucial role in the antiplasmodial effect together with thiazinoquinone ring system planarity; moreover, in the active regioisomers, the length of alkyl side chain distinguishes the antiplasmodial from the cytotoxic activity. The whole of our results supports the hypothesis that the antiplasmodial activity of thiazinoquinones is related to their capacity to form toxic semiquinone species, with the thiazinoquinone ring system planarity favoring the reductive activation of parent quinone. Finally, electrochemical studies strongly evidenced the relationship between the antiplasmodial activity and an intense interaction with $\mathrm{Fe}(\mathrm{III})$-heme, achieved through the formation of surface confined $\mathbf{Q H}-\mathbf{F e}(\mathrm{III})-$ heme adducts. The good agreement between the "electrochemical activity", tentatively expressed as function of the $\left|\Delta E_{\mathrm{p}}^{\mathrm{VMP}}\right|$ measured for thiazinoquinones 15-22, and in vitro antiplasmodial activity suggests that solid state voltammetry could represent a high sensitivity and quite inexpensive method for the rapid screening of active molecules in the class of antimalarial thiazinoquinones.

\section{Acknowledgements}

This work was supported by EU project Bluegenics (grant number 311848) and Italian MIUR (FIRB project: RBFR12WB3W_003).

\section{References}

1 R. G. Ridley, Nature, 2002, 415, 686.

2 J. L. Weisman, A. P. Liou, A. A. Shelat, F. E. Cohen, R. Kiplin Guy and J. L. deRisi, Chem. Biol. Drug Des., 2006, 67, 409.

3 T. N. Wells, P. L. Alonso and W. E. Gutteridge, Nat. Rev. Drug Discovery, 2009, 8, 879.

4 T. Rodrigues, R. Moreira and F. Lopes, Future Med. Chem., 2011, 3, 1.

5 F. Gamo, L. M. Sanz, J. Vidal, C. de Cozar, E. Alvarez, J. Lavandera, D. E. Vanderwall, D. V. S. Green, V. Kumar, S. Hasan, J. R. Brown, C. E. Peishoff, L. R. Cardon and J. F. Garcia-Bustos, Nature, 2010, 465, 305.

6 D. A. Fidock, Nature, 2010, 465, 297.

7 J. Bero, M. Michel Frederich and J. Quetin-Leclercq, J. Pharm. Pharmacol., 2009, 61, 1401.

8 K. Kaur, M. Jain, T. Kaur and R. Jain, Bioorg. Med. Chem., 2009, 17, 3229.

9 C. R. Nogueira and L. M. X. Lopes, Molecules, 2011, 16, 2146.

10 E. Fattorusso and O. Taglialatela-Scafati, Mar. Drugs, 2009, 7, 130.

11 K. R. Watts, K. Tenney and P. Crews, Curr. Opin. Biotechnol., 2010, 21, 808.

12 D. Laurent, V. Jullian, A. Parenty, M. Knibiehler, D. Dorin, S. Schmitt, O. Lozach, N. Lebouvier, M. Frostin, F. Alby, S. Maurel, C. Doerig, L. Meijer and M. Sauvain, Bioorg. Med. Chem., 2006, 14, 4477.

13 A. Longeon, B. R. Copp, M. Roué, J. Dubois, A. Valentin, S. Petek, C. Debitus and M. Bourguet-Kondracki, Bioorg. Med. Chem., 2010, 18, 6006.

14 R. A. Davis, S. Duffy, S. Fletcher, V. M. Avery and R. J. Quinn, J. Org. Chem., 2013, 78, 9608.

15 G. L. Nixon, D. M. Moss, A. E. Shone, D. G. Lalloo, N. Fisher, P. M. O'Neill, S. A. Ward and G. A. Biagini, J. Antimicrob. Chemother., 2013, 68, 977.

16 A. Aiello, E. Fattorusso, P. Luciano, A. Mangoni and M. Menna, Eur. J. Org. Chem., 2005, 5024.

17 A. Aiello, E. Fattorusso, P. Luciano, M. Menna, M. A. Calzado, E. Munoz, F. Bonadies, M. Guiso, M. F. Sanasi, G. Cocco and R. Nicoletti, Bioorg. Med. Chem., 2010, 18, 719.

18 F. J. Schmitz and S. J. Bloor, J. Org. Chem., 1988, 53, 3922.

19 R. M. Scribner, J. Org. Chem., 1966, 31, 3671.

20 K. Ehrhardt, E. Davioud-Charvet, H. Ke, A. B. Vaidya, M. Lanzer and M. Deponte, Antimicrob. Agents Chemother., 2013, 57, 2114.

21 P. S. Guin, S. Das and P. C. Mandal, Int. J. Electrochem., 2011, 816202. 
22 A. O. Colson and M. D. Sevilla, J. Phys. Chem., 1995, 99, 13033.

23 P. K. Chattaraj, U. Sarkar and D. R. Roy, Chem. Rev., 2006, 106, 2065.

24 J. J. Kessl, N. V. Moskalev, G. W. Gribble, M. Nasr, S. R. Meshnick and B. L. Trumpower, Biochim. Biophys. Acta, 2007, 1767, 319.

25 A. Saleh, J. Friesen, S. Baumeister, U. Gross and W. Bohne, Antimicrob. Agents Chemother., 2007, 51, 1217.

26 T. Müller, L. Johann, B. Jannack, M. Bruckner, D. A. Lanfranchi, H. Bauer, C. Sanchez, V. Yardley, C. Deregnaucourt, J. Schrevel, M. Lanzer, R. H. Schirmer and E. Davioud-Charvet, J. Am. Chem. Soc., 2011, 133, 11557.

27 E. Davioud-Charvet and D. A. Lanfranchi, Subversive substrates of glutathione reductases from Plasmodium falciparum-infected red blood cells as antimalarial agents, in Drug discovery in infectious diseases, ed. P. Selzer, WileyVCH, Weinheim, Germany, 2011, vol. 2, pp. 375-396.

28 O. Blank, E. Davioud-Charvet and M. Elhabiri, Antioxid. Redox Signaling, 2012, 17, 544.

29 F. Scholz and B. Meyer, Voltammetry of solid microparticles immobilized on electrode surfaces, in Electroanalytical Chemistry, A Series of Advances, ed. A. J. Bard and I. Rubinstein, CRC Press, Boca Raton, FL, 1998, vol. 20, pp. 1-86.

30 F. Scholz, U. Schröder and R. Gulabowski, Electrochemistry of immobilized particles and droplets, in Monographs in Electrochemistry Series, ed. F. Scholz, Springer, BerlinHeidelberg, 2005.

31 A. Doménech, J. Labuda and F. Scholz, Pure Appl. Chem., 2013, 85, 609.

32 A. Doménech, M. T. Doménech, M. C. Saurí, J. V. Gimeno and F. Bosch, Anal. Bioanal. Chem., 2003, 375, 1169.

33 T. Grygar, S. Kuckova, D. Hradil and D. Hradilova, J. Solid State Electrochem., 2003, 7, 706.

34 A. Doménech, M. T. Doménech and M. C. Saurí, Talanta, 2005, 66, 769.

35 Š. Komorsky-Lovrić and I. Novak, J. Food Sci., 2011, 76, C916.
36 M. T. de Groot, Electrochemistry of Immobilized Hemes and Heme Proteins, Eindhoven University Technology, Eindhoven, the Netherlands, 2007, ch. 7.

37 A. Doménech-Carbó, A. Maciuk, B. Figadère, E. Popuon and G. Cebrián-Torrejón, Anal. Chem., 2013, 85, 4014.

38 Y. Zhang and J. B. Zheng, Electrochim. Acta, 2007, 52, 7210.

39 D. Nematollahi, A. Ariapad and M. Rafiee, J. Electroanal. Chem., 2007, 602, 37.

40 W. Trager and J. B. Jensen, Science, 1976, 193, 673.

41 S. Parapini, N. Basilico, E. Pasini, T. J. Egan, P. Olliaro, D. Taramelli and D. Monti, Exp. Parasitol., 2000, 96, 249.

42 M. T. Makler, J. M. Ries, J. A. Williams, J. E. Bancroft, R. C. Piper, B. L. Gibbins and D. J. Hinrichs, Am. J. Trop. Med. Hyg., 1993, 48, 739.

43 M. Casagrande, A. Barteselli, N. Basilico, S. Parapini, D. Taramelli and A. Sparatore, Bioorg. Med. Chem., 2012, 20, 5965 .

44 S. D'Alessandro, M. Gelati, N. Basilico, E. A. Parati, R. K. Haynes and D. Taramelli, Toxicology, 2007, 241, 66.

45 ACD/Percepta, version 14.0.0, Advanced Chemistry Development, Inc., Toronto, ON, Canada, 2013, http:// www.acdlabs.com.

46 J. R. Maple, M. J. Hwang, T. P. Stockfisch, U. Dinur, M. Waldman, C. S. Ewig and A. T. Hagler, J. Comput. Chem., 1994, 15, 162.

47 R. Fletcher, Unconstrained Optimization, in Practical Methods of Optimization, John Wiley \& Sons, New York, 1980, vol. 1.

48 J. P. Stewart, MOPAC2012, Stewart Computational Chemistry, Colorado Springs, CO, USA, http:/www.OpenMOPAC.net, 2012.

49 J. Baker, J. Comput. Chem., 1986, 7, 385.

50 R. G. Parr, L. Szentplay and S. Lui, J. Am. Chem. Soc., 1999, 121, 1922.

51 A. Sawyer, E. Sullivan and Y. H. Mariam, J. Comput. Chem., 1996, 17, 204. 